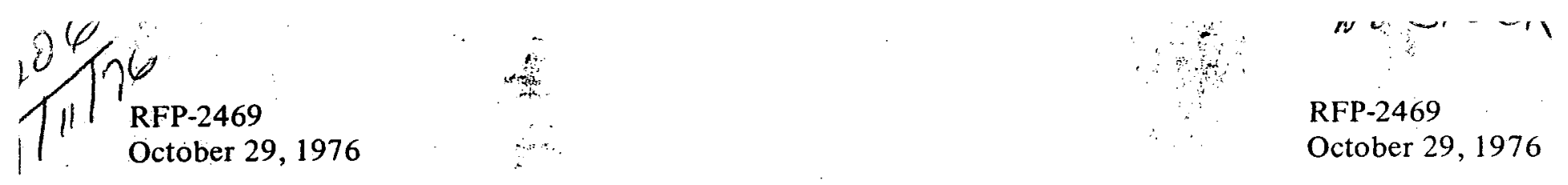

\title{
RADIOLYTIC GAS GENERATION IN PLUTONIUM CONTAMINATED WASTE MATERIALS
}

\author{
Armen R. Kazanjian
}

Chemistry Research and Development, PRODUCT INTEGRITY AND SURVEILLANCE GROUP

\section{Rockwell International}

Atomics International Divilelon

Rocky Flats Plant

P.O. Box 464

Golden. Colorado 80401

U.S. ENERGY RESEARCH AND DEVELOPMENT ADMINISTRATION CONTRACT EY-76-C-04-3533 


\section{DISCLAIMER}

This report was prepared as an account of work sponsored by an agency of the United States Government. Neither the United States Government nor any agency Thereof, nor any of their employees, makes any warranty, express or implied, or assumes any legal liability or responsibility for the accuracy, completeness, or usefulness of any information, apparatus, product, or process disclosed, or represents that its use would not infringe privately owned rights. Reference herein to any specific commercial product, process, or service by trade name, trademark, manufacturer, or otherwise does not necessarily constitute or imply its endorsement, recommendation, or favoring by the United States Government or any agency thereof. The views and opinions of authors expressed herein do not necessarily state or reflect those of the United States Government or any agency thereof. 


\section{DISCLAIMER}

Portions of this document may be illegible in electronic image products. Images are produced from the best available original document. 
Printed

October 29, 1976
RFP-2469

UC-70 NUCLEAR WASTE

MANAGEMENT

TID-4500-R64

\title{
RADIOLYTIC GAS GENERATION IN PLUTONIUM CONTAMINATED WASTE MATERIALS
}

\author{
Armen R. Kazanjian
}

Chemistry Research and Development, PRODUCT INTEGRITY AND SURVEILLANCE GROUP

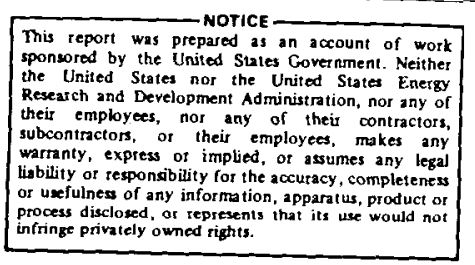

\section{SUBJECT DESCRIPTORS}

Waste Storage

Radioactive Wastes

Radiation Effects

Plutonium Residue

ROCKWELL INTERNATIONAL

ATOMICS INTERNATIONAL DIVISION

\begin{abstract}
ROCKY FLATS PLANT
\end{abstract}
P.O. BOX 464

GOLDEN, COLORADO 80401

Prepared under Contract EY-76-C-04-3533

for the

Albuquerque Operations Office

U.S. Energy Research and Development Administration

This document is

PUBLICLY RELEASABLE Lama \& Hóliame

Authorizing Official

Date: $07 / 20 / 2007$ 
RFP-2469

\section{CONTENTS}

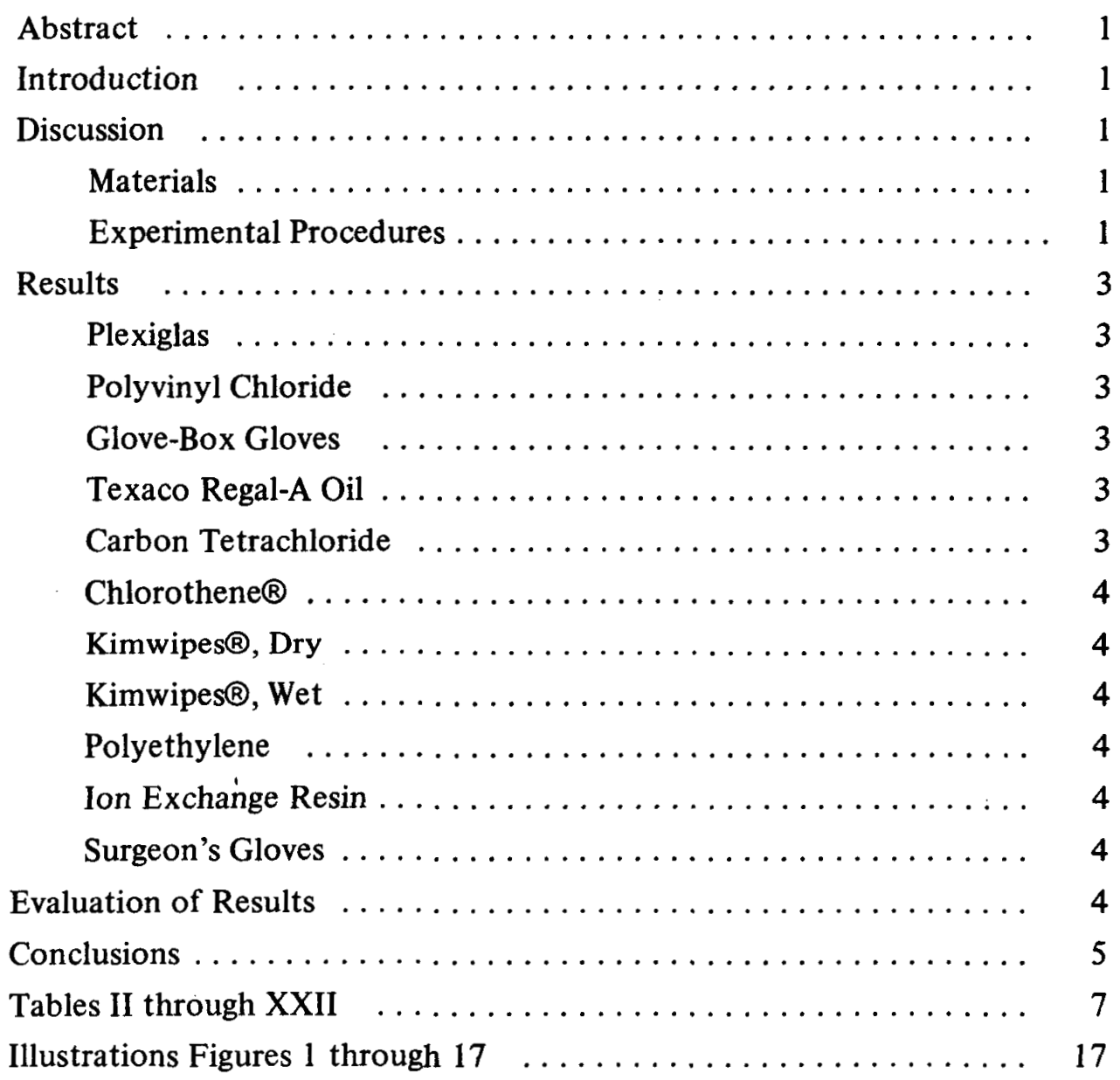

\section{A CK NOWLEDGMENTS}

The author greatly appreciates the work done by Harold O. Pitts and Richard E. Schlupp in obtaining all of the analyses by mass spectrometry. 


\title{
RADIOLYTIC GAS GENERATION IN PLUTONIUM CONTAMINATED WASTE MATERIALS
}

\author{
Armen R. Kazanjian
}

\begin{abstract}
Many plutonium contaminated waste materials decompose into gaseous products because of exposure to alpha radiation. The gases generated (usually hydrogen) over long-storage periods may create hazardous conditions. To determine the extent of such hazards, knowing the gas generation yields is necessary. These yields were measured by contacting some common Rocky Flats Plant waste materials with plutonium and monitoring the enclosed atmospheres for extensive periods of time. The materials were Plexiglas, polyvinyl chloride, glove-box gloves, machining oil, carbon tetrachloride, chlorothene $\mathrm{VG}{ }^{\circledR}$ solvent, Kimwipes $\circledast$ (dry and wet), polyethylene, Dowex-1 resin, and surgeon's gloves. Both plutonium-239 oxide and plutonium-238 oxide were used as radiation sources. The gas analyses were made by mass spectrometry and the results obtained were the total gas generation, the hydrogen generation, the oxygen consumption rate, and the gas composition over the entire storage period. Hydrogen was the major gas produced in most of the materials. The total gas yields varied from 0.71 to 16 cubic centimetres (standard temperature pressure) per day per curie of plutonium. The oxygen consumption rates varied from 0.0088 to 0.070 millimoles per day per gram of plutonium oxide- 239 and from 0.0014 to 0.0051 millimoles per day per milligram plutonium 238 .
\end{abstract}

\section{INTRODUCTION}

A large variety of radioactive waste materials is produced relative to plutonium operations at Rocky Flats Plant. Many of these materials are organic compounds which decompose into gaseous products when exposed to the alpha radiation from plutonium. Although the gas yields are relatively small, the amounts produced over longstorage periods could be considerable. The storage times are presently projected for 20 years so that the gas formation in the 55-gallon storage drums is of concern. The information required to predict the gas formation has been obtained by contacting a number of common Rocky Flats Plant waste materials with plutonium and monitoring the gas quantities and compositions over an extensive period of time. The materials were Plexiglas, polyvinyl chloride, glove-box gloves, machining oil, carbon tetrachloride, chlorothene $₫$ solvent, Kimwipes@ (dry and wet), polyethylene, Dowex-1 resin, and surgeon's gloves.

The experiments were made up of two series. The first series, consisting of 6 materials in contact with plutonium 239 (Pu-239), has continued for 470 days. The second series, consisting of 6 materials in contact with plutonium $238(\mathrm{Pu}-238)$, has continued for 267 days.

\section{DISCUSSION}

\section{Materials:}

The description and amounts of material used, the plutonium weights, and the free volume in the containers are listed in Table I.

\section{Experimental Procedures:}

The experiments were conducted to obtain the maximum gas yields by maximizing the contact between plutonium and material. This was achieved by using a large surface area of material and small plutonium oxide particles. The plutonium239 oxide $\left(\mathrm{PuO}_{2}-239\right)$ was passed through a $30-$ micrometre mesh screen. Almost all of the alpha radiation would escape from these particles since the range of an alpha particle in plutonium dioxide is about 10 micrometres. The plutonium-238 oxide was not screened, but a particle size analysis showed that essentially all of the particles were less than 20 micrometres and most were in the 2-micrometre range.

Most of the materials, originally in sheet form, were cut into small pieces by repetitively passing them through a mechanical shredder. The glove-box 
TABLE I. Materials in Contact with Plutonium.

\begin{tabular}{|c|c|c|c|}
\hline \multicolumn{2}{|r|}{ Material } & $\begin{array}{l}\text { Plutonium } \\
\text { Oxide } 239 \\
\text { Weight } \\
\text { (grams) }\end{array}$ & $\begin{array}{l}\text { Free Volume } \\
\left(\begin{array}{c}\text { cubic } \\
\text { centimetres }\end{array}\right)\end{array}$ \\
\hline 1. & $\begin{array}{l}\text { Plexiglas, } \\
\text { rod stock, } 12.8 \text { grams }\end{array}$ & 1.0 & 208 \\
\hline 2. & $\begin{array}{l}\text { Polyvinyl Chloride, } \\
\text { standard O-ring bags at } \\
\text { Rocky Flats, } 37.3 \text { grams }\end{array}$ & 1.0 & 190 \\
\hline 3. & $\begin{array}{l}\text { Glove-box Gloves, } 30 \text {-mil } \\
\text { lead-lined Neoprene- } \\
\text { Hypalon gloves used at } \\
\text { Rocky Flats, } 82.8 \text { grams }\end{array}$ & 1.0 & 186 \\
\hline 4. & $\begin{array}{l}\text { Texaco Regal-A machining } \\
\text { oil ( } 30 \text { cubic centimetres) }\end{array}$ & 1.0 & 185 \\
\hline 5. & $\begin{array}{l}\text { Carbon Tetrachloride } \\
\text { ( } 30 \text { cubic centimetres) }\end{array}$ & 1.0 & 185 \\
\hline \multirow[t]{2}{*}{6.} & Chlorothene-VG® solvent- & 1.0 & 185 \\
\hline & Material & $\begin{array}{l}\text { Plutonium } \\
238 \text { Weight } \\
\text { (milligrams) }\end{array}$ & $\begin{array}{l}\text { Free Volume } \\
\left(\begin{array}{c}\text { cubic } \\
\text { centimetres }\end{array}\right)\end{array}$ \\
\hline 7. & $\begin{array}{l}\text { Kimwipes@ (Dry), cellulosic } \\
\text { material used at Rocky } \\
\text { Flats for cleaning, } 4.87 \text { grams }\end{array}$ & 7.3 & 181 \\
\hline 8. & $\begin{array}{l}\text { Kimwipes@ (Wet), water } \\
\text { added to dry Kimwipes, } \\
11.85 \text { grams, dry weight } \\
4.80 \text { grams }\end{array}$ & 5.5 & 155 \\
\hline 9. & $\begin{array}{l}\text { Polyethylene, 3-mil thick } \\
\text { bags used at Rocky Flats, } \\
3.61 \text { grams }\end{array}$ & 9.0 & 180 \\
\hline 10. & $\begin{array}{l}\text { Polyvinyl Chloride, standard } \\
\text { O-ring bags at Rocky Flats } \\
18.30 \text { grams }\end{array}$ & 13.5 & 145 \\
\hline 11. & $\begin{array}{l}\text { Ion Exchange Resin, Dowex } \\
1 \times 4 \text { in nitrate form, } 50 \text { to } \\
100 \text { mesh, contains about } \\
20 \text { percent water, } \\
28.08 \text { grams }\end{array}$ & 6.9 & 136 \\
\hline 12. & $\begin{array}{l}\text { Surgeon's Gloves, natural } \\
\text { latex gloves used at Rocky } \\
\text { Flats, } 15.81 \text { grams }\end{array}$ & 9.7 & 162 \\
\hline
\end{tabular}

gloves were cut up with a scissors and the Plexiglas was prepared by generating turnings on a lathe and crushing all by hand. A well-dispersed mixture was obtained by adding the plutonium oxide $\left(\mathrm{PuO}_{2}\right)$ to the material in increments and shaking or stirring the mixture in a container.
The three liquids were prepared by mixing one gram of plutonium dioxide with 5 grams of Microcell@ (calcium silicate that is used for a liquid absorbent at Rocky Flats) and then admixing 30 cubic centimetres $\left(\mathrm{cm}^{3}\right)$ of the liquid to form a paste. The alpha radiation in these liquids would be well distributed and completely absorbed. The fraction (about 15 percent) of the energy absorbed by the Microcell@ must be discounted and does not contribute significantly to the gas generation because calcium silicate is relatively radiation stable.

The plutonium-239 oxide appeared to be welldispersed, although some of the oxide in the Plexiglas and glove-box gloves was on the bottom of the container and not on the surface of the material. Even with these materials, most of the radiation is probably absorbed by the material. With plutonium 238 , approximately 10 -milligram amounts of oxide were used so that it was not visible.

The mixtures were placed in valved stainless steel containers whose volumes were approximately 215 cubic centimetres. Air at approximately 81.1 kilopascals ( 610 torr) pressure was the original atmosphere. The atmospheres in the containers were sampled periodically for pressure and gas composition. The pressure measurements were made with a Wallace and Tiernan differential pressure gage. The gas analyses were made with a CEC-104 mass spectrometer. Each sampling removed 3.0 and $2.5 \mathrm{~cm}^{3}$, for the first and second series, respectively. The corrected pressures are included in Tables II through XVIII appearing at the end of text, see Page 7. The first series of tests (Pu-239) were carried out in two stages. After 120 days, the containers were partially evacuated to obtain the free volumes. The containers were then backfilled with helium to varying degrees as indicated in Tables VIII through XII. The sampling and analyses were then continued for another 347 days. The change in atmosphere should not and did not appear to affect the radiolytic gas generation. The free volumes in the second series ( $\mathrm{Pu}-238)$ were measured after the last sample was taken.

These tests were continued for long periods to determine if the gas generation rates remained constant. After a given time, depending on the 
material and the size of the plutonium particle, the gas generation will slow down as the material around each particle becomes depleted through radiolytic decomposition. Since movement of the particles would eliminate this effect, disturbance of the samples was held to a minimum. The samples had to be transported across a room for every analysis so that it is unknown whether the plutonium particles were moved. For the last two analyses, the samples had to be transported between buildings so there was a greater possibility for movement.

\section{RESULTS}

The data obtained are reported in Tables II through XVIII. The amounts of total gas, hydrogen, and oxygen are plotted as function of time in Figures 1 through 17 appearing at the end of text following the tables, Page 17. The first series of samples were evacuated after 120 days of contact time so that an additional set of curves (Figures 7 through 11) was required for the new pressures. The results on each material will be discussed individually, followed by some general observations and conclusions.

\section{Plexiglas:}

The total pressure decreased the first 17 days as a result of oxygen depletion and then increased linearly for about 200 days. The gas generation rate then declined slowly over the remaining 250 days. This appears to be an example of material depletion. The main radiolysis product is carbon monoxide, and carbon dioxide is produced at about the same rate as hydrogen. The hydrogen rate is the only one plotted in all the figures because there is the greatest concern about the amount of hydrogen produced on long storage. The hydrogen rate is essentially linear up to about the last 50 days so that most of the decrease in rate of total pressure must be attributed to the other gaseous components. The higher rate shown in the second column (100-200 days) of Table XIX (Page 16) can be attributed to air leakage into the container.

\section{Polyvinyl Chloride:}

The total pressure (using Pu-239) decreased the first 35 days as a result of oxygen depletion and then increased linearly for the remainder of the test period. Hydrogen, the predominant product, increased at a constant rate. Although it is known that hydrogen chloride is a main radiolysis product, ${ }^{1}$ it has not been detected analytically probably because of prior reaction. With $\mathrm{Pu}-238$ after an initial decrease for 15 days, the total pressure increased linearly up to 150 days, then appeared to begin leveling off. The gas generation rate obtained with $\mathrm{Pu}-238$ is about one-half that obtained with $\mathrm{Pu}-239$. The discrepancy is not clear, but it may be due to $\mathrm{Pu}-238$ not well dispersed in the material.

\section{Glove-Box Gloves:}

The total pressure decreased the first 60 days as a result of oxygen depletion and then increased almost linearly from then on. The rate appears to be slowly declining over the entire range. Hydrogen and carbon dioxide are the main radiolysis products.

\section{Texaco Regal-A Oil:}

The total gas pressure increases linearly over the entire test period. The last point indicates a decrease in rate, but more data would be required to confirm this. No decrease in initial pressure was noted because the radiolytic reaction of oxygen is too slow to offset the relatively large rate of hydrogen production. Hydrogen, the main product, increases linearly after a somewhat slower rate for the first 50 days.

\section{Carbon Tetrachloride:}

The only gaseous product analyzed in carbon tetrachloride was carbon dioxide, and after the oxygen was completely depleted in about 40 days the production rate became essentially nil. The source of the carbon dioxide is puzzling because previous studies ${ }^{2}$ have shown that chlorine and phosgene are the only gaseous products. Chlorine was not detected, probably because of its reactivity. Phosgene reacts with water to form carbon dioxide but the source of so much water (greater than one millimole) is unknown.

\footnotetext{
${ }^{1}$ A. A. Miller. "Radiation Chemistry of Polyvinyl Chloride." Journal of Physical Chemistry 63:1755. 1959.

${ }^{2}$ J. W. T. Spinks and R. J. Woods. An Introduction to Radiation Chemistry. John Wiley and Sons, New York. 1964. Page 233. (Also same article by Zd. Spurny and I Janovsky in Nature 190:624. 1961.)
} 


\section{Chlorothene $\AA^{\circledR}$}

The total pressure declined for the first 30 days because of oxygen depletion, then increased. There appears to be air leakage at some points [note nitrogen $\left(\mathrm{N}_{2}\right)$ and argon (Ar) concentrations in Table XII, Page 121 after 150 days, so that the total pressure increase thereafter is questionable. The main products are hydrogen, carbon dioxide, and dichloroethylene. The formation of this last compound infers the production of hydrogen chloride, which was not detected probably because of its reactivity.

\section{Kimwipes®, Dry:}

The total pressure increased almost linearly throughout the test period. The rate for the first 50 days is somewhat slower because of oxygen depletion and the rate is starting to fall off after 200 days probably because of material depletion. Hydrogen and carbon dioxide are the main products. The rate of hydrogen production starts to decrease. after about 130 days.

\section{Kimwipes $®$, Wet:}

The total pressure increased linearly throughout the test period. The rate is significantly lower than that from dry Kimwipes because of the high water content. Water is relatively radiation stable. ${ }^{3}$ Hydrogen and carbon dioxide are the main products. The rate of hydrogen production starts to decline after 120 days.

\section{Polyethylene:}

The total pressure decreased for the first 10 days because of oxygen depletion. The rate of increase shows a slight decline for the next 100 days and then appears constant for the remainder of the test period. Hydrogen, the main product, shows a slowly declining rate.

\section{Ion Exchange Resin:}

The total pressure decreased the first 50 days because of oxygen depletion and then increased

\footnotetext{
${ }^{3}$ J. W. T. Spinks and R. J. Woods. An Introduction to Radiation Chemistry. John Wiley and Sons, New York. 1964. Page 250.
}

linearly over the entire range. Hydrogen and carbon dioxide are the main products. The rate of hydrogen production is constant except for a slight decline over the last 50 days.

\section{Surgeon's Gloves:}

The total pressure decreased the first 30 days because of oxygen depletion. The pressure then increases at a gradually decreasing rate over the entire range. Hydrogen, the main product, follows the same pattern.

\section{EVALUATION OF RESULTS}

The rates of gas generation are listed in Tables XIX through XXII (Page 16) using three types of units. The gas yields listed in Tables XX (Page 16) and XXI and the first column of Table XIX are maximum yields obtained from the slopes of the curves after oxygen depletion. The rates have been calculated using 0.0692 curies per gram $\mathrm{Pu}-239,0.00211$ watts per gram $\mathrm{Pu}-239,17.1$ curies per gram PU-238, and 0.567 watts per gram $\mathrm{Pu}-238$ as conversion factors. The factors for $\mathrm{Pu}-239$ are high because of the presence of other plutonium isotopes.

The G-values (Table XXI) are the numbers of molecules produced per $100 \mathrm{eV}$ of absorbed energy . These values are approximately the same as those obtained previously using gamma radiation ${ }^{4}$ indicating that the plutonium was fairly welldispersed and the maximum yields have probably been reasonably achieved. Exact comparisons are not given because of the variation in these types of materials and the difference between alpha and gamma radiation.

The rates of radiation induced oxygen consumption are shown in Table XXII. The oxygen is reacted to form carbon dioxide, carbon monoxide, and nonvolatile oxidation products from the various materials. Comparison of the oxygen consumption rates with the gas generation rates indicates the extent to which the total pressure will decrease before becoming larger. For example, the gas production rate in Texaco oil is so much larger than the rate of oxygen depletion that the overall

\footnotetext{
${ }^{4}$ R. O. Bolt and J. G. Carroll, editors. Radiation Effects on Organic Materials. Academic Press, New York. 1963. Page 239.
} 
pressure increases linearly from the start. The total pressure over the Kimwipes (dry and wet) increases from the start, even though gas production and oxygen depletion are essentially the same because almost all of the oxygen is utilized to form carbon dioxide so that there is no net loss in pressure. Each experiment must be analyzed individually. The time for complete oxygen depletion is, of course, dependent on the free volume of air. In storage drums with free volumes on the order of 100 litres, exceptionally long times would be required for the total pressure to decrease and then increase to atmospheric pressure, assuming carbon dioxide or carbon monoxide were not major products.

These tests were continued for a long period to determine whether the rates would decrease because of material depletion. In many cases the rates had decreased as shown in the figures. The rates shown in the second and third columns of Table XIX are approximate measurements of the slopes at the specified periods. Unfortunately, definite conclusions can not be drawn because of three factors. One, there is no assurance that the oxide particles were stationary throughout the test period. This was discussed in the experimental section. Movement of the particles can decrease the rates by falling to the bottom of the container as well as increase the rates by contacting fresh material. Two, the exact dispersion of the oxide particles in the solid materials is not known. Particles in close proximity will contribute radiation to the same volume and hasten the decomposition. The extent of this is unknown so that it is difficult to make predictions from the data that have been obtained. Three, the results obtained from $\mathrm{Pu}-238$ and $\mathrm{Pu}-239$ radiation are inconsistent. The main reason $\mathrm{Pu}-238$ was used in the second series was that its dosage is about 200 times that of $\mathrm{Pu}-239$. Therefore, the material around each $\mathrm{Pu}-238$ oxide particle should be depleted 200 times faster. There should have been more indication of this effect even though different materials were used in each series. Polyvinyl chloride was irradiated by both sources and does show some evidence. The gas generation rate from polyvinyl chloride is constant for the entire period of irradiation with $\mathrm{Pu}-239$, whereas the rate appears to decrease after about 6 months of irradiation with $\mathrm{Pu}-238$.
Calculations show that the material around a 10-micrometre size particle of $\mathrm{Pu}-238$ should be completely decomposed in a few months. This duration with regard to gas generation depends on the decomposition rate of the radiolysis products, as well as that of the starting material. With 10-micrometre size Pu-239 particles, the material would not be depleted for many years. These results are not in accord with the observations that some of the rates with $\mathrm{Pu}-239$ were decreasing and some of the rates with $\mathrm{Pu}-238$ were constant. More experiments irradiating the same materials with both sources are required to determine the extent of this dose rate effect.

The most important factor in material depletion is the size of the plutonium particle. If the sizes are on the order of atomic dimensions and there is the usual excess of material, the material would never be depleted. If the particle sizes are greater than about 30 micrometres, the depletion times would not be much less than a few months because an appreciable fraction of the radiation is then absorbed by the plutonium.

\section{CONCLUSIONS}

The gas generation rates produced by exposure of Rocky Flats Plant waste materials to alpha radiation from plutonium have been obtained in two series of tests. In one series, materials were contacted with plutonium 239 for 470 days and in the other series, materials were contacted with plutonium 238 for 267 days. The gas yields, in units of standard cubic centimetres per day per curie of plutonium, varied from 16 for Texaco Regal-A machining oil to 0.71 for Dowex-1 ion exchange resin. The predominant gas in most of the materials was hydrogen.

Estimation of the hazards created in storage drums by the measured gas rates has not been made here because of its complexity. This topic should be the subject of another report. The results obtained here indicate that although significant overpressurization is possible, the probability is low. The probability depends on the material and many other factors. Appreciable amounts of hydrogen are usually produced, but will not be accompanied by oxygen in a drum for most of the storage period. 
RFP-2469

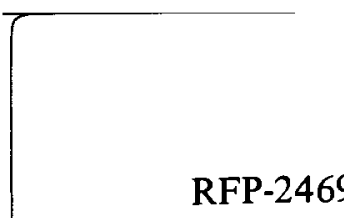

6


TABLES

II through XXII

TABLE II. Plexiglas, Gas Pressure and Composition, Irradiation from Plutonium 239.

\section{Days in Contact \\ *Pressure (torr) \\ Corrected Pressure (torr) \\ Millimoles Gas \\ Percent Gas Composition}

Nitrogen $\left(\mathrm{N}_{2}\right)$

Oxygen $\left(\mathrm{O}_{2}\right)$

Argon (Ar)

Hydrogen $\left(\mathrm{H}_{2}\right)$

Carbon Monoxide (CO)

Carbon Dioxide $\left(\mathrm{CO}_{2}\right)$

Methane $\left(\mathrm{CH}_{4}\right)$

Ethane $\left(\mathrm{C}_{2} \mathrm{H}_{6}\right)$

Other Hydrocarbons

$\begin{array}{rrrrrrrrr}1 & 6 & 12 & 19 & 30 & 44 & 61 & 82 & 100 \\ 605 & 580 & 558 & 545 & 563 & 598 & 645 & 669 & 704 \\ 613 & 596 & 581 & 576 & 604 & 650 & 711 & 747 & 798 \\ 6.80 & 6.62 & 6.45 & 6.39 & 6.70 & 7.22 & 7.89 & 8.29 & 8.86\end{array}$

$\begin{array}{lrrrrrrrr}78.7 & 79.5 & 82.9 & 87.2 & 81.8 & 82.9 & 75.6 & 65.6 & 62.9 \\ 19.5 & 13.6 & 7.0 & 0.3 & 0.1 & 0.2 & 0.6 & 0.2 & 0.3 \\ 0.9 & 0.9 & 0.9 & 1.0 & 1.0 & 0.9 & 0.7 & 0.8 & 0.7 \\ 0.09 & 0.6 & 1.3 & 2.3 & 3.2 & 4.6 & 5.7 & 7.4 & 8.2 \\ - & 3.6 & 4.4 & 3.9 & 6.7 & 2.5 & 6.0 & 14.5 & 15.2 \\ 0.2 & 1.2 & 2.4 & 4.1 & 5.6 & 6.3 & 7.2 & 7.8 & 8.3 \\ 0.06 & 0.3 & 0.6 & 1.0 & 1.5 & 2.2 & 3.0 & 3.4 & 3.8 \\ - & - & - & 0.04 & - & 0.03 & - & 0.1 & 0.06 \\ 0.04 & 0.05 & 0.3 & 0.2 & 0.1 & 0.3 & 1.0 & 0.2 & 0.5\end{array}$


RFP-2469

TABLE III. Polyvinyl Chloride, Gas Pressure and Composition, Irradiation from Plutonium 239.

$\begin{array}{lcccccccrr}\text { Days in Contact } & 1 & 6 & 12 & 19 & 30 & 44 & 61 & 82 & 100 \\ \text { *Pressure (torr) } & 605 & 588 & 567 & 550 & 523 & 522 & 541 & 559 & 577 \\ \text { Corrected Pressure (torr) } & 615 & 607 & 594 & 586 & 566 & 574 & 604 & 634 & 665 \\ \text { Millimoles Gas } & 6.21 & 6.13 & 6.00 & 5.92 & 5.72 & 5.80 & 6.10 & 6.40\end{array}$

Percent Gas Composition

Nitrogen $\left(\mathrm{N}_{2}\right)$

$\begin{array}{ccccccccc}78.8 & 79.5 & 82.6 & 84.3 & 86.4 & 92.0 & 85.6 & 80.4 & 78.2 \\ 19.8 & 17.3 & 14.0 & 10.3 & 4.3 & - & - & - & - \\ 0.8 & 0.9 & 0.9 & 1.0 & 1.0 & 1.0 & 0.9 & 0.9 & 0.9, \\ 0.1 & 0.8 & 1.5 & 3.1 & 5.4 & 4.6 & 10.4 & 14.8 & 17.2 \\ - & 0.8 & 0.05 & - & 1.1 & - & - & 0.5 & - \\ 0.1 & 0.2 & 0.3 & 0.6 & 1.0 & 1.5 & 2.2 & 2.3 & 2.4 \\ 0.02 & 0.03 & 0.04 & 0.07 & 0.1 & 0.2 & 0.3 & 0.4 & 0.4 \\ 0.02 & 0.1 & 0.1 & 0.2 & 0.5 & 0.5 & 0.4 & 0.3 & 0.4 \\ 0.04 & 0.05 & 0.2 & 0.2 & 0.2 & 0.2 & 0.3 & 0.4 & 0.4\end{array}$

Oxygen $\left(\mathrm{O}_{2}\right)$

Argon (Ar)

Hydrogen $\left(\mathrm{H}_{2}\right)$

Carbon Monoxide (CO)

Carbon Dioxide $\left(\mathrm{CO}_{2}\right)$

Methane $\left(\mathrm{CH}_{4}\right)$

Ethane $\left(\mathrm{C}_{2} \mathrm{H}_{6}\right)$

Other Hydrocarbons

*For SI (metric) use: 1 torr $=133$ pascals.

TABLE IV. Glove-Box Gloves, Gas Pressure and Composition, Irradiation from Plutonium 239.

\begin{tabular}{|c|c|c|c|c|c|c|c|c|c|}
\hline Days in Contact & 1 & 6 & 12 & 19 & 30 & 44 & 61 & 82 & 100 \\
\hline *Pressure (torr) & 608 & 591 & 580 & 567 & 546 & 524 & $491^{\prime}$ & 492 & 496 \\
\hline Corrected Pressure (torr) & 618 & 610 & 608 & 604 & 591 & 576 & 548 & 558 & 572 \\
\hline Millimoles Gas & 6.14 & 6.06 & 6.04 & 6.00 & 5.87 & 5.73 & 5.45 & 5.55 & 5.69 \\
\hline \multicolumn{10}{|l|}{ Percent Gas Composition } \\
\hline Nitrogen $\left(\mathrm{N}_{2}\right)$ & 77.9 & 78.1 & 79.0 & 80.8 & 82.4 & 87.0 & 91.3 & 88.8 & 87.0 \\
\hline Oxygen $\left(\mathrm{O}_{2}\right)$ & 20.7 & 19.6 & 17.6 & 15.7 & 12.5 & 6.9 & 0.3 & - & - \\
\hline Argon (Ar) & 0.9 & 0.9 & 0.9 & 1.0 & 1.0 & 1.0 & 1.0 & 1.1 & 1.0 \\
\hline Hydrogen $\left(\mathrm{H}_{2}\right)$ & 0.05 & 0.4 & 0.7 & 1.3 & 2.0 & 2.7 & 3.8 & 5.6 & 6.7 \\
\hline Carbon Monoxide (CO) & - & 0.4 & 0.8 & - & 0.3 & - & - & - & - \\
\hline Carbon Dioxide $\left(\mathrm{CO}_{2}\right)$ & 0.1 & 0.3 & 0.6 & 1.0 & 1.5 & 2.2 & 3.4 & 4.3 & 5.0 \\
\hline Methane $\left(\mathrm{CH}_{4}\right)$ & 0.02 & 0.02 & - & 0.03 & 0.04 & 0.06 & 0.08 & 0.1 & 0.2 \\
\hline Ethane $\left(\mathrm{C}_{2} \mathrm{H}_{6}\right)$ & - & 0.02 & - & - & 0.05 & - & - & - & - \\
\hline Other Hydrocarbons & 0.02 & - & 0.1 & 0.05 & - & 0.1 & 0.06 & 0.06 & 0.06 \\
\hline
\end{tabular}


TABLE V. Texaco Regal-A Oil, Gas Pressure and Composition, Irradiation from Plutonium 239.

\begin{tabular}{|c|c|c|c|c|c|c|c|c|c|}
\hline Days in Contact & 1 & 6 & 12 & 19 & 30 & 44 & 61 & 82 & 100 \\
\hline *Pressure (torr) & 656 & 664 & 678 & 698 & 724 & 769 & 824 & 888 & 951 \\
\hline Corrected Pressure (torr) & 665 & 685 & 711 & 743 & 783 & 845 & 920 & 1008 & 1097 \\
\hline Millimoles Gas & 6.58 & 6.77 & 7.03 & 7.35 & 7.74 & 8.36 & 9.10 & 9.97 & 10.85 \\
\hline \multicolumn{10}{|l|}{ Percent Gas Composition } \\
\hline Nitrogen $\left(\mathrm{N}_{2}\right)$ & 76.9 & 75.6 & 74.8 & 71.6 & 68.4 & 65.5 & 60.7 & 53.0 & 48.8 \\
\hline Oxygen $\left(\mathrm{O}_{2}\right)$ & 20.8 & 19.9 & 18.1 & 17.0 & 13.9 & 11.3 & 8.3 & 6.3 & 4.6 \\
\hline Argon (Ar) & 0.9 & 0.9 & 0.8 & 0.8 & 0.8 & 0.7 & 0.7 & 0.7 & 0.6 \\
\hline Hydrogen $\left(\mathrm{H}_{2}\right)$ & 0.3 & 2.5 & 5.6 & 9.7 & 15.6 & 20.8 & 28.3 & 37.5 & 43.2 \\
\hline Carbon Monoxide (CO) & 0.7 & 0.7 & - & - & - & - & - & - & - \\
\hline Carbon Dioxide $\left(\mathrm{CO}_{2}\right)$ & 0.08 & 0.07 & 0.06 & 0.07 & 0.07 & 0.06 & 0.2 & 0.1 & 0.1 \\
\hline Methane $\left(\mathrm{CH}_{4}\right)$ & 0.02 & 0.03 & 0.1 & 0.1 & 0.2 & 0.3 & 0.4 & 0.5 & 0.5 \\
\hline Ethane $\left(\mathrm{C}_{2} \mathrm{H}_{6}\right)$ & 0.02 & 0.1 & 0.2 & 0.4 & 0.6 & 0.9 & 1.3 & 1.4 & 1.6 \\
\hline Other Hydrocarbons & 0.04 & 0.04 & 0.08 & 0.1 & 0.2 & 0.3 & 0.07 & 0.4 & 0.5 \\
\hline
\end{tabular}

*For SI (metric) use: 1 torr $=133$ pascals.

TABLE VI. Carbon Tetrachloride, Gas Pressure and Composition, Irradiation from Plutonium 239.

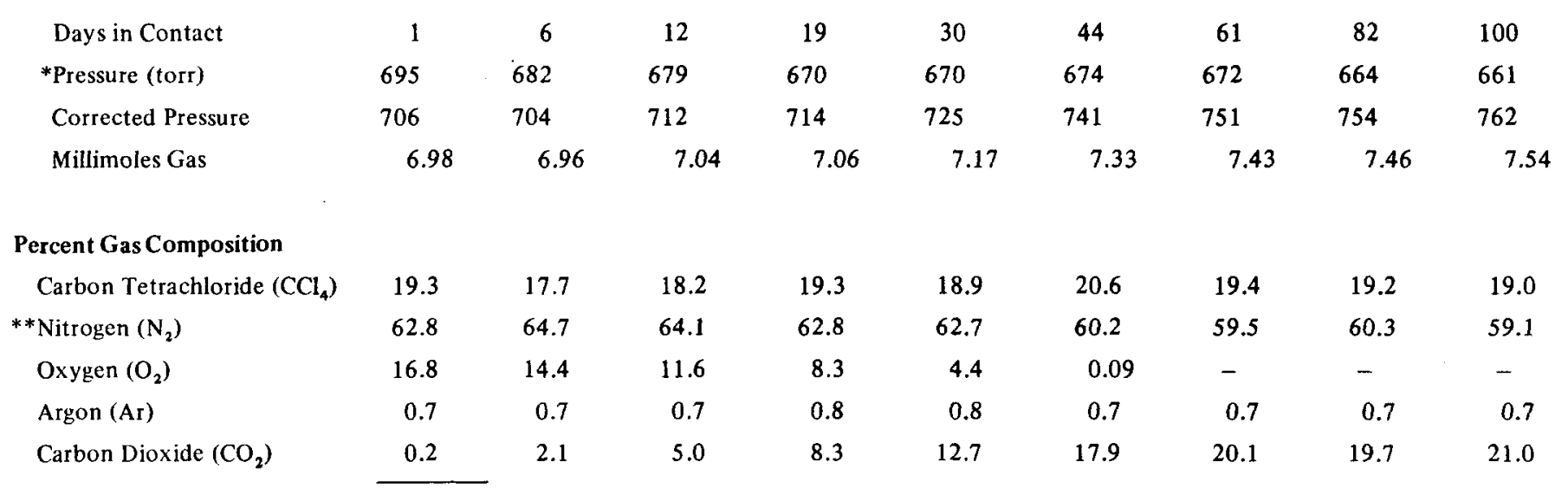

*For SI (metric) use: 1 torr $=133$ pascals.

**The nitrogen and carbon monoxide gas analyses are indistinguishable in this case. 
TABLE VII. Chlorothene®, Gas Pressure and Composition, Irradiation from Plutonium 239.

\begin{tabular}{|c|c|c|c|c|c|c|c|c|c|}
\hline Days is Contact & 1 & 6 & 12 & 19 & 30 & 44 & 61 & 82 & 100 \\
\hline *Pressure (torr) & 692 & 662 & 642 & 625 & 607 & 623 & 634 & 646 & 661 \\
\hline Corrected Pressure (torr) & 703 & 683 & 673 & 666 & 657 & 685 & 708 & 733 & 762 \\
\hline Millimoles Gas & 6.95 & 6.75 & 6.66 & 6.59 & 6.50 & 6.77 & 7.00 & 7.25 & 7.54 \\
\hline \multicolumn{10}{|l|}{ Percent Gas Composition } \\
\hline Chlorothene $\left(\mathrm{C}_{2} \mathrm{H}_{3} \mathrm{Cl}_{3}\right)$ & 22.4 & 22.3 & 20.6 & 22.2 & 22.9 & 24.4 & 22.9 & 21.5 & 20.6 \\
\hline$* *$ Nitrogen $\left(\mathrm{N}_{2}\right)$ & 60.7 & 63.4 & 66.3 & 68.0 & 69.8 & 65.7 & 63.8 & 62.8 & 61.2 \\
\hline Oxygen $\left(\mathrm{O}_{2}\right)$ & 15.9 & 13.0 & 9.8 & 5.1 & - & - & - & - & - \\
\hline Argon (Ar) & 0.6 & 0.7 & 0.8 & 0.8 & 0.8 & 0.8 & 0.8 & 0.7 & 0.7 \\
\hline Hydrogen $\left(\mathrm{H}_{2}\right)$ & 0.06 & 0.3 & 0.6 & 1.1 & 1.7 & 2.3 & 3.2 & 4.4 & 5.5 \\
\hline Carbon Dioxide $\left(\mathrm{CO}_{2}\right)$ & 0.08 & 0.2 & 0.6 & 1.2 & 2.6 & 4.1 & 5.9 & 6.1 & 6.6 \\
\hline Methane $\left(\mathrm{CH}_{4}\right)$ & - & - & 0.1 & 0.2 & 0.2 & 0.2 & 0.3 & 0.4 & 0.6 \\
\hline Ethane $\left(\mathrm{C}_{2} \mathrm{H}_{6}\right)$ & - & - & 0.6 & 0.4 & 0.4 & 0.4 & 0.4 & 0.3 & 0.2 \\
\hline Other Hydrocarbons & - & - & 0.3 & 0.8 & 1.6 & 2.1 & 2.8 & 3.7 & 4.5 \\
\hline
\end{tabular}

*For Si (metric) use: 1 torr $=133$ pascals.

**The nitrogen and carbon monoxide gas analyses are indistinguishable in this case.

TABLE VIII. Plexiglas, Gas Pressure and Composition, Irratiation from Plutonium 239.

\begin{tabular}{|c|c|c|c|c|c|c|c|c|c|}
\hline${ }^{a}$ Days in Contact & 0 & 31 & 80 & 116 & 157 & 200 & 252 & 300 & 347 \\
\hline b Pressure (torr) & 246 & 366 & 520 & 591 & 660 & 717 & 757 & 804 & 844 \\
\hline Corrected Pressure (torr) ${ }^{\circ}$ & 250 & 377 & 543 & 626 & 709 & 781 & 836 & 901 & 960 \\
\hline Millimoles Gas & 2.78 & 4.18 & 6.03 & 6.95 & 7.87 & 8.67 & 9.28 & 10.0 & 10.7 \\
\hline \multicolumn{10}{|l|}{ Percent Gas Composition } \\
\hline Nitrogen $\left(\mathrm{N}_{2}\right)$ & 21.6 & 26.9 & 26.9 & 24.3 & 22.5 & 19.6 & 19.9 & 17.5 & 15.1 \\
\hline Oxygen $\left(\mathrm{O}_{2}\right)$ & 0.8 & 0.8 & 0.7 & - & - & - & - & - & - \\
\hline Argon (Ar) & 0.07 & 0.2 & 0.3 & 0.3 & 0.3 & 0.2 & 0.2 & 0.2 & 0.2 \\
\hline Hydrogen $\left(\mathrm{H}_{2}\right)$ & 4.0 & 7.5 & 10.2 & 11.5 & 12.8 & 21.6 & 16.0 & 16.6 & 16.7 \\
\hline Carbon Monoxide (CO) & 7.2 & 13.8 & 18.2 & 20.5 & 22.4 & 21.4 & 26.8 & 27.5 & 29.9 \\
\hline Carbon Dioxide $\left(\mathrm{CO}_{2}\right)$ & 7.4 & 8.0 & 12.0 & 10.8 & 12.0 & 11.7 & 13.5 & 14.2 & 14.8 \\
\hline Methane $\left(\mathrm{CH}_{4}\right)$ & 2.7 & 4.1 & 5.2 & 4.9 & 5.4 & 5.3 & 6.5 & 6.9 & 7.0 \\
\hline Ethane $\left(\mathrm{C}_{2} \mathrm{H}_{6}\right)$ & - & - & 0.2 & 0.5 & 0.5 & 0.5 & 0.6 & 0.6 & 0.7 \\
\hline Other Hydrocarbons & 1.8 & 1.5 & 0.3 & c 4.7 & c 4.1 & c 4.2 & c 2.5 & c $\quad 3.4$ & c 3.8 \\
\hline Helium (He) & 54.3 & 37.2 & 25.9 & 21.0 & 18.5 & 14.3 & 13.0 & 11.7 & 10.6 \\
\hline & & $\begin{array}{l}a_{P} \\
b_{F} \\
c_{M}\end{array}$ & $\begin{array}{l}120 \text { days } \\
\text { SI (metric } \\
\text { anol }(\mathrm{CH}\end{array}$ & $\begin{array}{l}\text { fore pump } \\
\text { ise: } 1 \text { torr } \\
\text { H). }\end{array}$ & $\begin{array}{l}\text { ut. } \\
133 \text { pascal }\end{array}$ & & & & \\
\hline
\end{tabular}


RFP-2469

TABLE IX. Polyvinyl Chloride, Gas Pressure and Composition, Irradiation from Plutonium 239.

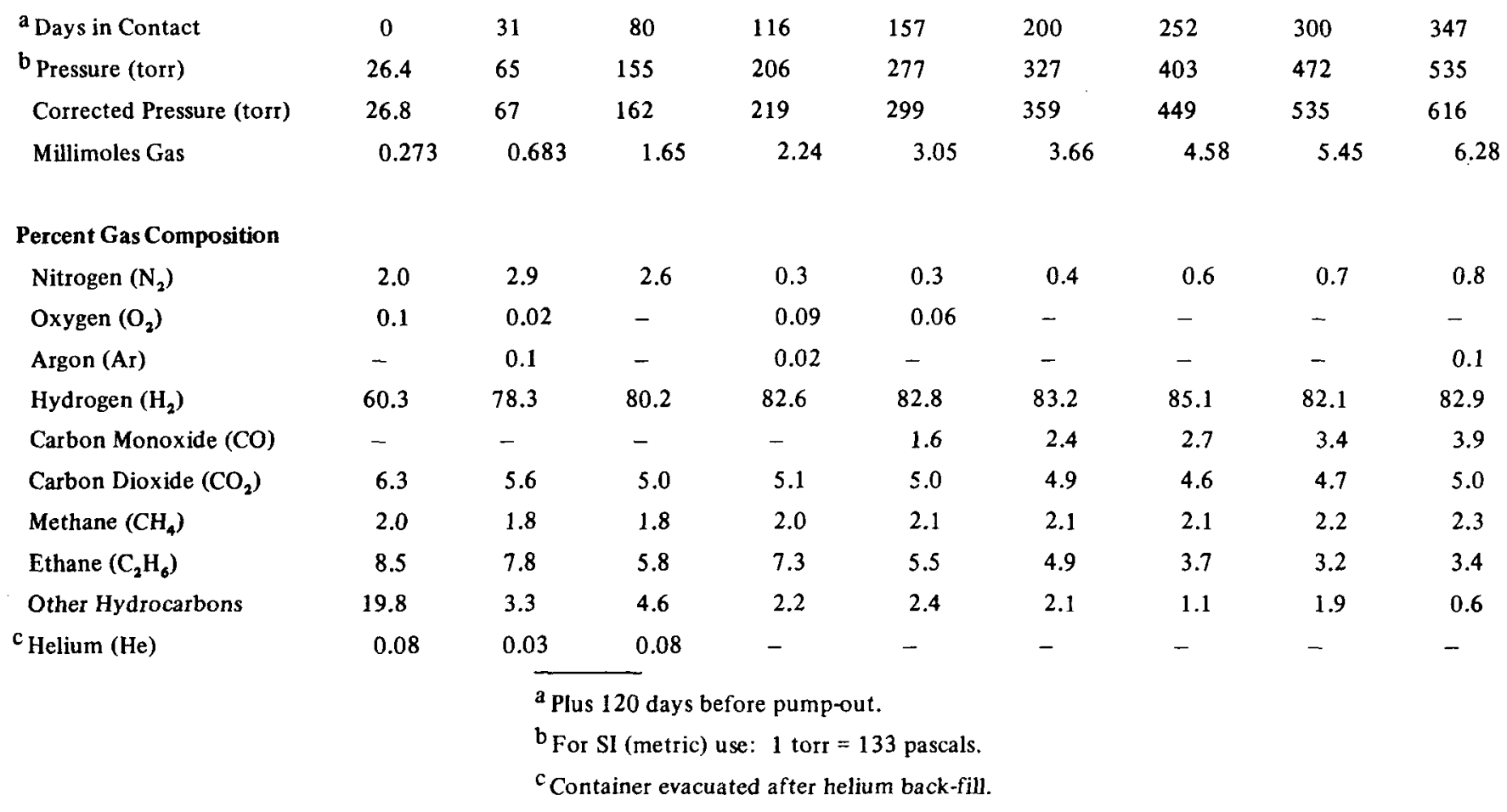

TABLE X. Glove-Box Gloves, Gas Pressure and Composition, Irradiation from Plutonium 239.

\begin{tabular}{|c|c|c|c|c|c|c|c|c|c|}
\hline${ }^{a}$ Days in Contact & 0 & 31 & 80 & 116 & 157 & 200 & 252 & 300 & 347 \\
\hline $\mathrm{b}_{\text {Pressure (torr) }}$ & 13.2 & 30 & 63 & 80 & 96 & 110 & 122 & 142 & 158 \\
\hline Corrected Pressure (torr) & 13.4 & 31 & 66 & 85 & 104 & 121 & 136 & 161 & 182 \\
\hline Millimoles Gas & 0.133 & 0.308 & 0.656 & 0.848 & 1.03 & 1.20 & 1.35 & 1.60 & 1.81 \\
\hline \multicolumn{10}{|l|}{ Percent Gas Composition } \\
\hline Nitrogen $\left(\mathrm{N}_{2}\right)$ & 16.7 & 10.3 & 7.0 & 6.3 & 6.0 & 6.7 & 5.8 & 6.1 & 6.1 \\
\hline Oxygen $\left(\mathrm{O}_{2}\right)$ & 0.1 & 0.1 & 0.1 & 0.09 & 0.09 & 0.06 & - & - & 0.4 \\
\hline Argon (Ar) & 0.3 & 0.3 & 0.2 & 0.2 & 0.2 & 0.2 & 0.2 & 0.2 & 0.2 \\
\hline Hydrogen $\left(\mathrm{H}_{2}\right)$ & 23.1 & 44.6 & 52.6 & 56.3 & 60.3 & 64.0 & 65.8 & 67.6 & 67.5 \\
\hline Carbon Monoxide (CO) & 1.1 & 2.7 & 4.5 & 5.0 & 5.8 & 3.4 & 6.1 & 5.8 & 6.5 \\
\hline Carbon Dioxide $\left(\mathrm{CO}_{2}\right)$ & 42.4 & 34.3 & 30.6 & 27.8 & 23.9 & 22.2 & 19.1 & 17.4 & 16.9 \\
\hline Methane $\left(\mathrm{CH}_{4}\right)$ & 0.6 & 0.8 & 1.0 & 1.2 & 1.3 & 1.4 & 1.4 & 1.4 & 1.6 \\
\hline Ethane $\left(\mathrm{C}_{2} \mathrm{H}_{0}\right)$ & 0.8 & 1.1 & 0.6 & 0.6 & 0.4 & 0.3 & 0.2 & 0.2 & 0.1 \\
\hline Other Hyorocarbons & 1.1 & 0.1 & 0.5 & 0.3 & 0.05 & 0.08 & 0.09 & 0.06 & 0.06 \\
\hline Helium (He) & 13.8 & 5.7 & 3.0 & 2.3 & 1.9 & 1.6 & 1.3 & 1.1 & 1.0 \\
\hline
\end{tabular}


TABLE XI. Texaco Regal-A Oil, Gas Pressure and Composition, Irradiation from Plutonium 239.

$\begin{array}{lcccccrrrr}\text { a Days in Contact } & 0 & 31 & 80 & 116 & 157 & 200 & 252 & 300 & 347 \\ \text { b Pressure (torr) } & 142 & 280 & 500 & 625 & 792 & 947 & 1110 & 1265 & 1320 \\ \text { Corrected Pressure (torr) } & 144 & 289 & 525 & 666 & 858 & 1042 & 1241 & 1437 & 1523 \\ \text { Millimoles Gas } & 1.42 & 2.86 & 5.19 & 6.59 & 8.48 & 10.3 & 12.3 & 14.2\end{array}$

\section{Percent Gas Composition}

Nitrogen $\left(\mathrm{N}_{2}\right)$

Oxygen $\left(\mathrm{O}_{2}\right)$

Argon (Ar)

Hydrogen $\left(\mathrm{H}_{2}\right)$

Carbon Dioxide $\left(\mathrm{CO}_{2}\right)$

Methane $\left(\mathrm{CH}_{4}\right)$

Ethane $\left(\mathrm{C}_{2} \mathrm{H}_{6}\right)$

Other Hydrocarbons

Helium (He)

$\begin{array}{rcccccccc}13.1 & 8.3 & 5.5 & 3.2 & 2.3 & 1.9 & 1.4 & 1.2 & 0.8 \\ 0.5 & 0.02 & 0.02 & - & - & - & - & - & - \\ 0.4 & 0.4 & 0.2 & 0.3 & 0.7 & 0.2 & 0.1 & 0.2 & 0.2 \\ 37.5 & 65.6 & 76.7 & 80.5 & 83.0 & 85.1 & 86.5 & 87.1 & 87.2 \\ 0.3 & 0.2 & 0.04 & 0.09 & 0.2 & 0.04 & - & - & - \\ 0.6 & 1.0 & 1.1 & 1.2 & 1.3 & 1.3 & 1.3 & 1.3 & 1.4 \\ 3.9 & 3.9 & 3.5 & 5.1 & 4.6 & 5.2 & 4.9 & 5.1 & 5.4 \\ 7.7 & 1.5 & 1.7 & 1.1 & 1.3 & 1.1 & 1.7 & 1.3 & 1.2 \\ 35.2 & 18.9 & 10.6 & 8.0 & 6.1 & 4.9 & 3.9 & 3.4 & 3.0\end{array}$

a Plus 120 days before pump-out.

$b_{\text {For }} S I$ (metric) use: 1 torr $=133$ pascals.

TABLE XII. Chlorothene-VG®, Gas Pressure and Composition, Irradiation from Plutonium 239.

\begin{tabular}{|c|c|c|c|c|c|c|c|c|c|}
\hline${ }^{a}$ Days in Contact & 0 & 31 & 80 & 116 & 157 & 200 & 252 & 300 & 347 \\
\hline $\mathrm{b}_{\text {Pressure (torr) }}$ & 322 & 338 & 450 & 504 & 552 & 585 & 588 & 671 & 785 \\
\hline Corrected Pressure (torr) & 327 & 349 & 472 & 537 & 598 & 643 & 657 & 762 & 906 \\
\hline Millimoles Gas & 3.24 & 3.45 & 4.67 & 5.31 & 5.91 & 6.36 & 6.50 & 7.54 & 8.96 \\
\hline \multicolumn{10}{|l|}{ Percent Gas Composition } \\
\hline Nitrogen $\left(\mathrm{N}_{2}\right)$ & 4.0 & 9.1 & 7.4 & 7.4 & 10.7 & 14.2 & 17.7 & 11.6 & 11.8 \\
\hline Oxygen $\left(\mathrm{O}_{2}\right)$ & - & - & - & - & - & - & - & - & - \\
\hline Argon (Ar) & 0.04 & 0.1 & 0.07 & 0.08 & 0.1 & 0.2 & 0.2 & 0.1 & 0.1 \\
\hline Hydrogen $\left(\mathrm{H}_{2}\right)$ & 2.0 & 5.8 & 5.9 & 7.8 & 13.0 & 14.8 & 18.2 & 16.4 & 15.9 \\
\hline Carbon Monoxide (CO) & - & - & 0.3 & 1.2 & 2.6 & 3.4 & 0.4 & 2.3 & 0.08 \\
\hline Carbon Dioxide $\left(\mathrm{CO}_{2}\right)$ & 2.5 & 3.6 & 7.7 & 10.5 & 14.0 & 15.1 & 14.5 & 11.8 & 10.4 \\
\hline Methane $\left(\mathrm{CH}_{4}\right)$ & 0.4 & 0.6 & 0.6 & 0.7 & 1.0 & 1.5 & 1.7 & 1.6 & 1.5 \\
\hline Ethane $\left(\mathrm{C}_{2} \mathrm{H}_{6}\right)$ & 0.6 & 0.3 & 0.6 & 0.8 & 0.3 & 0.3 & 0.4 & 0.7 & 1.1 \\
\hline Other Hydrocarbons & 2.8 & 4.8 & 4.1 & 4.7 & c 7.1 & c 9.6 & c 9.9 & c 9.3 & c 10.2 \\
\hline Helium (He) & 41.7 & 36.6 & 16.3 & 15.4 & 18.4 & 18.6 & 17.7 & 13.7 & 12.1 \\
\hline Chlorothene-VG & 46.0 & 39.0 & 57.0 & 51.5 & 32.8 & 22.3 & 19.3 & 32.4 & 36.7 \\
\hline
\end{tabular}

aplus 120 days before pump-out.

${ }^{b}$ For SI (metric) use: 1 torr $=133$ pascals.

${ }^{c}$ Dichlorothylene $\left(\mathrm{CH}_{2}=\mathrm{CCl}_{2}\right)$. 
TABLE XIII. Kimwipes®, Dry, Gas Pressure and Composition, Irradiation from Plutonium 238.

\begin{tabular}{|c|c|c|c|c|c|c|c|c|c|c|}
\hline Days in Contact & 0 & 2 & 8 & 21 & 36 & 77 & 120 & 175 & 220 & 267 \\
\hline *Pressure (torr) & 624 & 607 & 619 & 629 & 644 & 739 & 838 & 933 & 1004 & 1068 \\
\hline Corrected Pressure (torr) & 633 & 624 & 645 & 664 & 689 & 802 & 922 & 1041 & 1135 & 1224 \\
\hline Millimoles Gas & 6.12 & 6.03 & 6.24 & 6.42 & 6.67 & 7.76 & 8.92 & 10.1 & 11.0 & 11.8 \\
\hline \multicolumn{11}{|l|}{ Percent Gas Composition } \\
\hline Nitrogen $\left(\mathrm{N}_{2}\right)$ & 77.1 & 77.3 & 75.4 & 72.8 & 71.6 & 59.2 & 52.0 & 45.5 & 41.6 & 38.8 \\
\hline Oxygen $\left(\mathrm{O}_{2}\right)$ & 21.0 & 19.9 & 17.7 & 11.6 & 5.8 & 0.05 & - & - & - & - \\
\hline Argon (Ar) & 1.0 & 1.0 & 0.9 & 0.8 & 0.8 & 0.7 & 0.6 & 0.6 & 0.5 & 0.5 \\
\hline Hydrogen $\left(\mathrm{H}_{2}\right)$ & 0.06 & 1.1 & 3.8 & 8.6 & 12.8 & 20.7 & 26.3 & 30.7 & 33.2 & 33.4 \\
\hline Carbon Monoxide (CO) & 0.3 & - & - & 1.2 & 0.3 & 5.3 & 5.4 & 4.9 & 4.6 & 5.5 \\
\hline Carbon Dioxide $\left(\mathrm{CO}_{2}\right)$ & 0.1 & 0.4 & 1.4 & 3.6 & 7.2 & 12.4 & 14.4 & 16.8 & 17.9 & 19.4 \\
\hline Methane $\left(\mathrm{CH}_{4}\right)$ & 0.02 & 0.04 & 0.1 & 0.2 & 0.4 & 0.6 & 0.6 & 0.8 & 1.0 & 1.0 \\
\hline Ethane $\left(\mathrm{C}_{2} \mathrm{H}_{6}\right)$ & 0.02 & 0.03 & 0.07 & 0.1 & 0.3 & 0.3 & 0.2 & 0.4 & 0.4 & 0.5 \\
\hline Other Hydrocarbons & - & 0.05 & 0.4 & 0.8 & 0.4 & 0.7 & 0.5 & 0.3 & 0.6 & 0.4 \\
\hline Water $\left(\mathrm{H}_{2} \mathrm{O}\right)$ & $>0.3$ & $>0.3$ & $>0.3$ & $>0.2$ & $>0.2$ & - & - & $>0.05$ & 0.3 & 0.4 \\
\hline
\end{tabular}

*For SI (metric) use: 1 torr $=133$ pascals.

TABLE XIV. Kimwipes $\circledast$, Wet, Gas Pressure and Composition, Irradiation from Plutonium 238.

\begin{tabular}{|c|c|c|c|c|c|c|c|c|c|c|}
\hline Days in Contact & 0 & 2 & 8 & 21 & 36 & 77 & 120 & 175 & 220 & 267 \\
\hline *Pressure (torr) & 370 & 369 & 368 & 369 & 372 & 412 & 456 & 491 & 526 & 559 \\
\hline Corrected Pressure (torr) & 376 & 381 & 386 & 393 & 403 & 453 & 510 & 558 & 607 & 655 \\
\hline Millimoles Gas & 3.11 & 3.15 & 3.20 & 3.25 & 3.34 & 3.75 & 4.22 & 4.62 & 5.03 & 5.43 \\
\hline
\end{tabular}

\section{Percent Gas Composition}

\begin{tabular}{|c|c|c|c|c|c|c|c|c|c|c|}
\hline Nitrogen $\left(\mathrm{N}_{2}\right)$ & 76.3 & 76.5 & 69.0 & 70.2 & 70.9 & 64.5 & 58.0 & 51.0 & 48.4 & 44.3 \\
\hline Oxygen $\left(\mathrm{O}_{2}\right)$ & 20.3 & 20.7 & 18.0 & 14.0 & 10.0 & 1.1 & - & - & - & - \\
\hline Argon (AI) & 0.9 & 1.0 & 0.9 & 0.9 & 0.9 & 0.8 & 0.7 & 0.6 & 0.6 & 0.6 \\
\hline Hydrogen $\left(\mathrm{H}_{2}\right)$ & 0.04 & 0.7 & 2.2 & 6.0 & 9.9 & 19.0 & 26.4 & 33.5 & 36.2 & 39.5 \\
\hline Carbon Monoxide (CO) & - & - & 1.3 & 0.2 & - & 1.2 & 2.0 & 1.6 & 1.0 & 2.6 \\
\hline Carbon Dioxide $\left(\mathrm{CO}_{2}\right)$ & 0.1 & 0.3 & 1.1 & 2.7 & 5.7 & 10.6 & 11.2 & 11.2 & 11.4 & 11.7 \\
\hline Methane $\left(\mathrm{CH}_{4}\right)$ & - & 0.03 & 0.03 & 0.04 & 0.07 & 0.1 & 0.2 & 0.2 & 0.2 & 0.3 \\
\hline Ethane $\left(\mathrm{C}_{2} \mathrm{H}_{6}\right)$ & 0.03 & 0.04 & 0.04 & 0.06 & 0.1 & 0.2 & 0.1 & 0.1 & 0.1 & 0.1 \\
\hline Other Hydrocarbons & - & - & - & - & 0.3 & 0.06 & 0.1 & 0.1 & 0.2 & 0.05 \\
\hline Water $\left(\mathrm{H}_{2} \mathrm{O}\right)$ & $>2.3$ & $>0.8$ & $>\quad 7.4$ & $>\quad 5.8$ & $>\quad 2.4$ & $>2.6$ & $>\quad 1.3$ & $>1.6$ & $>\quad 1.9$ & $>0.9$ \\
\hline
\end{tabular}

*For SI (metric) use: 1 torr $=133$ pascals. 
TABLE XV. Polyethylene, Gas Pressure and Composition, Irradiation from Plutonium 238.

\begin{tabular}{|c|c|c|c|c|c|c|c|c|c|c|c|}
\hline Days in Contact & 0 & & 2 & 8 & 21 & 36 & 77 & 120 & 175 & 220 & 267 \\
\hline *Pressure (torr) & 622 & & 609 & 570 & 598 & 648 & 766 & 875 & 970 & 1051 & 1128 \\
\hline Corrected Pressure (torr) & 631 & & 626 & 594 & 632 & 694 & 832 & 963 & 1083 & 1189 & 1294 \\
\hline Millimoles Gas & 6.07 & & 6.02 & 5.71 & 6.08 & 6.68 & 8.00 & 9.27 & 10.4 & 11.4 & 12.5 \\
\hline \multicolumn{12}{|l|}{ Percent Gas Composition } \\
\hline Nitrogen $\left(\mathrm{N}_{2}\right)$ & 77.9 & & 79.0 & 84.8 & 78.9 & 73.5 & 58.3 & 49.6 & 44.4 & 40.2 & 38.0 \\
\hline Oxygen $\left(\mathrm{O}_{2}\right)$ & 20.6 & & 17.0 & 3.6 & - & - & - & - & - & - & - \\
\hline Argon (Ar) & 1.0 & & 1.0 & 0.9 & 1.0 & 0.9 & 0.7 & 0.6 & 0.5 & 0.5 & 0.5 \\
\hline Hydrogen $\left(\mathrm{H}_{2}\right)$ & 0.03 & & 2.0 & 6.6 & 14.2 & 20.2 & 34.0 & 42.0 & 50.5 & 54.5 & 57.7 \\
\hline Carbon Monoxide (CO) & - & & - & - & 1.1 & - & 2.0 & 2.9 & 0.4 & 0.8 & - \\
\hline Carbon Dioxide $\left(\mathrm{CO}_{2}\right)$ & 0.1 & & 0.5 & 2.5 & 3.5 & 4.2 & 3.9 & 3.5 & 3.0 & 2.7 & 2.6 \\
\hline Methane $\left(\mathrm{CH}_{4}\right)$ & 0.02 & & 0.03 & 0.09 & 0.3 & 0.4 & 0.4 & 0.9 & 0.5 & 0.6 & 0.6 \\
\hline Ethane $\left(\mathrm{C}_{2} \mathrm{H}_{6}\right)$ & 0.04 & & - & - & 0.1 & 0.2 & 0.3 & 0.3 & 0.3 & 0.3 & 0.4 \\
\hline Other Hydrocarbons & - & & 0.2 & 1.3 & 0.6 & 0.5 & 0.4 & 0.1 & 0.4 & 0.4 & 0.1 \\
\hline Water $\left(\mathrm{H}_{3} \mathrm{O}\right)$ & $>0.3$ & $>$ & 0.2 & $>\quad 0.4$ & $>0.4$ & $>0.2$ & - & - & - & 0.1 & 0.1 \\
\hline
\end{tabular}

TABLE XVI. Polyvinyl Chloride, Gas Pressure and Composition, Irradiation from Plutonium 238.

\begin{tabular}{|c|c|c|c|c|c|c|c|c|c|c|}
\hline Days in Contact & 0 & 2 & 8 & 21 & 36 & 77 & 120 & 175 & 220 & 267 \\
\hline *Pressure (torr) & 625 & 605 & 573 & 560 & 614 & 742 & 864 & 965 & 1060 & 1161 \\
\hline Corrected Pressure (torr) & 636 & 626 & 603 & 599 & 668 & 822 & 973 & 1106 & 1235 & 1376 \\
\hline Millimoles Gas & 4.93 & 4.85 & 4.67 & 4.65 & 5.18 & 6.37 & 7.54 & 8.57 & 9.57 & 10.7 \\
\hline \multicolumn{11}{|l|}{ Percent Gas Composition } \\
\hline Nitrogen $\left(\mathrm{N}_{2}\right)$ & 76.6 & 78.8 & 82.6 & 83.8 & 77.4 & 61.1 & 53.1 & 45.3 & 40.0 & 36.4 \\
\hline Oxygen $\left(\mathrm{O}_{2}\right)$ & 20.8 & 18.1 & 10.3 & - & - & - & - & - & - & - \\
\hline Argon (Ar) & 1.0 & 1.0 & 1.0 & 1.1 & 0.9 & 0.8 & 0.7 & 0.6 & 0.5 & 0.4 \\
\hline Hydrogen $\left(\mathrm{H}_{2}\right)$ & 0.1 & 1.0 & 4.4 & 10.7 & 16.5 & 28.2 & 36.6 & 45.4 & 49.9 & 52.8 \\
\hline Carbon Monoxide $(\mathrm{CO})$ & 1.0 & 0.4 & - & 1.1 & 0.9 & 5.0 & 4.1 & 3.0 & 3.3 & 4.0 \\
\hline Carbon Dioxide $\left(\mathrm{CO}_{2}\right)$ & 0.1 & 0.3 & 1.0 & 2.3 & 3.0 & 3.4 & 3.5 & 3.5 & 3.5 & 3.5 \\
\hline Methane $\left(\mathrm{CH}_{4}\right)$ & 0.02 & 0.04 & 0.1 & 0.3 & 0.6 & 1.0 & 1.2 & 1.5 & 1.6 & 1.7 \\
\hline Ethane $\left(\mathrm{C}_{2} \mathrm{H}_{6}\right)$ & 0.03 & 0.05 & 0.2 & 0.3 & 0.5 & 0.6 & 0.5 & 0.5 & 0.5 & 0.4 \\
\hline Other Hydrocarbons & 0.05 & 0.05 & 0.3 & 0.4 & 0.3 & 0.08 & 0.4 & 0.09 & 0.1 & 0.5 \\
\hline Water $\left(\mathrm{H}_{2} \mathrm{O}\right)$ & $>0.3$ & $>0.2$ & $>0.2$ & - & - & - & - & - & 0.5 & 0.3 \\
\hline
\end{tabular}


TABLE XVII. Ion Exchange Resin, Gas Pressure and Composition, Irradiation from Plutonium 238.

\begin{tabular}{|c|c|c|c|c|c|c|c|c|c|c|}
\hline Days in Contact & 0 & 2 & 8 & 21 & 36 & 77 & 120 & 175 & 220 & 267 \\
\hline *Pressure (torr) & 632 & 623 & 603 & 577 & 552 & 549 & 564 & 566 & 579 & 600 \\
\hline Corrected Pressure (torr) & 644 & 646 & 637 & 621 & 605 & 612 & 641 & 655 & 682 & 720 \\
\hline Millimoles Gas & 4.67 & 4.69 & 4.62 & 4.51 & 4.39 & 4.45 & 4.65 & 4.75 & 4.95 & 5.22 \\
\hline
\end{tabular}

\section{Percent Gas Composition}

Nitrogen $\left(\mathrm{N}_{2}\right)$

Oxygen $\left(\mathrm{O}_{2}\right)$

Argon (Ar)

Hydrogen $\left(\mathrm{H}_{2}\right)$

Carbon Monoxide (CO)

Carbon Dioxide $\left(\mathrm{CO}_{2}\right)$

Methane $\left(\mathrm{CH}_{4}\right)$

Ethane $\left(\mathrm{C}_{2} \mathrm{H}_{6}\right)$

Other Hydrocarbons

Water $\left(\mathrm{H}_{2} \mathrm{O}\right)$

\begin{tabular}{|c|c|c|c|c|c|c|c|c|c|}
\hline 77.6 & 77.0 & 77.4 & 81.3 & 83.8 & 83.9 & 81.6 & 79.9 & 78.6 & 74.2 \\
\hline 20.9 & 20.5 & 18.5 & 13.2 & 7.7 & - & - & - & - & - \\
\hline 1.0 & 1.0 & 1.0 & 1.1 & 1.0 & 1.0 & 1.0 & 1.0 & 0.9 & 0.9 \\
\hline 0.1 & 0.06 & 0.4 & 1.4 & 2.2 & 4.9 & 6.9 & 9.6 & 11.3 & 12.6 \\
\hline- & 1.1 & 0.6 & 0.1 & - & 2.1 & 2.9 & 0.9 & - & 1.2 \\
\hline 0.1 & 0.9 & 0.4 & 1.4 & 3.3 & 6.7 & 7.0 & 7.0 & 7.4 & 7.9 \\
\hline 0.02 & 0.03 & 0.06 & 0.1 & 0.2 & 0.3 & 0.4 & 0.6 & 0.7 & 0.8 \\
\hline 0.03 & 0.02 & 0.03 & 0.04 & 0.07 & 0.04 & 0.06 & 0.08 & 0.07 & 0.06 \\
\hline 0.05 & - & - & 0.04 & - & - & - & - & - & - \\
\hline 0.3 & $>0.2$ & $>1.6$ & $>1.4$ & $>\quad 1.7$ & $>1.1$ & - & 1.0 & $>1.0$ & $>2.4$ \\
\hline
\end{tabular}

*For SI (metric) use: 1 torr $=133$ pascals.

TABLE XVIII. Surgeon's Gloves, Gas Pressure and Composition, Irradiation from Plutonium 238.

\begin{tabular}{|c|c|c|c|c|c|c|c|c|c|c|}
\hline Days in Contact & 0 & 2 & 8 & 21 & 36 & 77 & 120 & 175 & 220 & 267 \\
\hline *Pressure (torr) & 625 & 616 & 602 & 575 & 573 & 654 & 725 & 784 & 842 & 893 \\
\hline Corrected Pressure (torr) & 635 & 635 & 630 & 611 & 618 & 717 & 807 & 886 & 966 & 1040 \\
\hline Millimoles Gas & 5.49 & 5.49 & 5.45 & 5.29 & 5.35 & 6.20 & 6.98 & 7.66 & 8.35 & 9.00 \\
\hline \multicolumn{11}{|l|}{ Percent Gas Composition } \\
\hline Nitrogen $\left(\mathrm{N}_{2}\right)$ & 76.7 & 77.8 & 77.8 & 80.9 & 82.6 & 69.4 & 61.2 & 53.8 & 50.0 & 46.9 \\
\hline Oxygen $\left(\mathrm{O}_{2}\right)$ & 21.4 & 20.0 & 16.6 & 6.7 & - & - & - & - & - & - \\
\hline Argon (Ar) & 1.0 & 1.0 & 1.0 & 1.1 & 1.0 & 0.8 & 0.7 & 0.7 & 0.6 & 0.5 \\
\hline Hydrogen $\left(\mathrm{H}_{2}\right)$ & - & 0.8 & 3.4 & 8.5 & 13.3 & 22.8 & 30.1 & 37.5 & 41.8 & 44.4 \\
\hline Carbon Monoxide (CO) & 0.6 & - & 0.3 & 1.0 & - & 2.8 & 3.2 & 2.9 & 2.0 & 2.3 \\
\hline Carbon Dioxide $\left(\mathrm{CO}_{2}\right)$ & 0.09 & 0.2 & 0.4 & 1.2 & 2.4 & 3.2 & 3.5 & 3.8 & 3.9 & 3.9 \\
\hline Methane $\left(\mathrm{CH}_{4}\right)$ & 0.02 & 0.03 & 0.07 & 0.2 & 0.4 & 0.6 & 0.7 & 0.9 & 1.1 & 1.1 \\
\hline Ethane $\left(\mathrm{C}_{2} \mathrm{H}_{6}\right)$ & 0.04 & 0.02 & 0.05 & 0.2 & 0.2 & 0.2 & 0.09 & 0.2 & 0.2 & 0.06 \\
\hline Other Hydrocarbons & - & - & 0.2 & 0.05 & 0.09 & 0.1 & 0.4 & 0.2 & 0.1 & 0.6 \\
\hline Water $\left(\mathrm{H}_{2} \mathrm{O}\right)$ & $>0.3$ & $>0.2$ & $>0.3$ & $>0.2$ & - & - & - & - & $>0.1$ & 0.2 \\
\hline
\end{tabular}

*For SI (metric) use: 1 torr $=133$ pascals. 
TABLE XIX. Gas Yields Generated by Plutonium 239.

\begin{tabular}{|c|c|c|c|}
\hline & \multicolumn{3}{|c|}{$\begin{array}{l}\text { Millimoles Gas per Day per Gram } \\
\text { Plutonium Dioxide }\end{array}$} \\
\hline & $\begin{array}{l}0 \text { to } 100 \\
\text { days }\end{array}$ & $\begin{array}{l}100 \text { to } 200 \\
\text { days }\end{array}$ & $\begin{array}{l}200 \text { to } 400 \\
\text { days }\end{array}$ \\
\hline Plexiglas & 0.031 & * 0.040 & 0.016 \\
\hline Polyvinyl Chloride & 0.016 & 0.017 & 0.017 \\
\hline Glove-Box Gloves & 0.0061 & 0.0062 & 0.0040 \\
\hline Texaco Oil & 0.043 & 0.043 & 0.043 \\
\hline Carbon Tetrachloride & 0.009 & - & - \\
\hline \multirow[t]{2}{*}{ Chlorothene-VG $\circledast$} & 0.015 & $* * 0.017$ & $* * 0.013$ \\
\hline & \multicolumn{3}{|c|}{$\begin{array}{c}\text { Cubic Centimetres } \\
\text { (standard temperature pressure) } \\
\text { Gas per Day per Curie Plutonium }\end{array}$} \\
\hline Plexiglas & 11 & 14 & 5.9 \\
\hline Polyvinyl Chloride & 5.9 & 6.2 & 6.2 \\
\hline Glove-Box Gloves & 2.2 & 2.3 & 1.5 \\
\hline Texaco Oil & 16 & 16 & 16 \\
\hline Carbon Tetrachloride & 3.3 & - & - \\
\hline Chlorothene-VG@ & 5.5 & 6.2 & 4.8 \\
\hline
\end{tabular}

*Refer to discussion under Plexiglas, Page 3.

**Refer to discussion under Chlorothene-VG, Page 4.

TABLE XX. Gas Yields Generated by Plutonium 238.

\begin{tabular}{|c|c|c|}
\hline & $\begin{array}{c}\text { Millimoles Gas } \\
\text { per Day per Milligram } \\
\text { Plutonium } 238 \\
\end{array}$ & $\left.\begin{array}{c}\text { Cubic Centimetres } \\
\text { (standard temperature } \\
\text { pressure }\end{array}\right)$ \\
\hline Kimwipes $\circledast$, Dry & 0.0032 & 4.2 \\
\hline Kimwipes®, Wet & 0.0016 & 2.1 \\
\hline *Polyethylene & 0.0037 & 4.9 \\
\hline *Polyvinyl Chloride & 0.0022 & 2.9 \\
\hline Ion Exchange Resin & 0.00054 & 0.71 \\
\hline *Surgeon's Gloves & 0.0020 & 2.6 \\
\hline
\end{tabular}

TABLE XXI. Gas Yields in Units of G-Values.

$\begin{array}{ll}\text { Plexiglas } & 1.9 \\ \text { Polyvinyl Chloride } & 0.96 \\ \text { Glove-Box Gloves } & 0.37 \\ \text { Texaco Oil } & * 2.6(3.1) \\ \text { Carbon Tetrachloride } & * 0.54(0.60) \\ \text { Chlorothene-VG@ } & * 0.90(1.0) \\ & \\ \text { Kimwipes@, Dry } & 0.63 \\ \text { Kimwipes®, Wet } & 0.31 \\ \text { Polyethylene } & 0.73 \\ \text { Polyvinyl Chloride } & 0.43 \\ \text { Ion Exchange Resin } & 0.11 \\ \text { Surgeon's Gloves } & 0.40\end{array}$

*These calculations are based on total energy absorption. Values in parentheses are approximate yields obtained when energy absorbed by Microcell@ is excluded.

The G-Values are equal to the number of molecules produced per 100 electron volts of absorbed energy.

TABLE XXII. Radiolytic Oxygen Consumption and Hydrogen Production.

\begin{tabular}{|c|c|c|}
\hline & $\begin{array}{c}\text { Millimoles Oxygen } \\
\text { per Day per Gram } \\
\text { Plutonium Dioxide } \\
239\end{array}$ & $\begin{array}{c}\text { Millimoles Hydrogen } \\
\text { per Day per Gram } \\
\text { Plutonium Dioxide } \\
239\end{array}$ \\
\hline Plexiglas & 0.070 & 0.0073 \\
\hline Polyvinyl Chloride & 0.034 & 0.012 \\
\hline Glove-Box Gloves & 0.019 & 0.0038 \\
\hline Texaco Oil & 0.0088 & 0.043 \\
\hline Carbon Tetrachloride & 0.030 & - \\
\hline \multirow[t]{2}{*}{ Chlorothene-VG® } & 0.042 & 0.0036 \\
\hline & $\begin{array}{c}\text { Millimoles Oxygen } \\
\text { per Day per Milligram } \\
\text { Plutonium } 238 \\
\end{array}$ & $\begin{array}{c}\text { Millimoles Hydrogen } \\
\text { per Day per Milligram } \\
\text { Plutonium } 238 \\
\end{array}$ \\
\hline Kimwipes@, Dry & 0.0034 & 0.0027 \\
\hline Kimwipes $\circledast$, Wet & 0.0014 & 0.0016 \\
\hline Polyethylene & 0.0014 & 0.0037 \\
\hline Polyvinyl Chloride & 0.0051 & 0.0017 \\
\hline Ion Exchange Resin & 0.0026 & 0.00038 \\
\hline Surgeon's Gloves & 0.0034 & 0.0019 \\
\hline
\end{tabular}




\section{ILLUSTRATIONS}

Figures 1 through 17

FIGURE 1. Plexiglas, Gas Production and Oxygen Depletion, Irradiation from Plutonium 239.

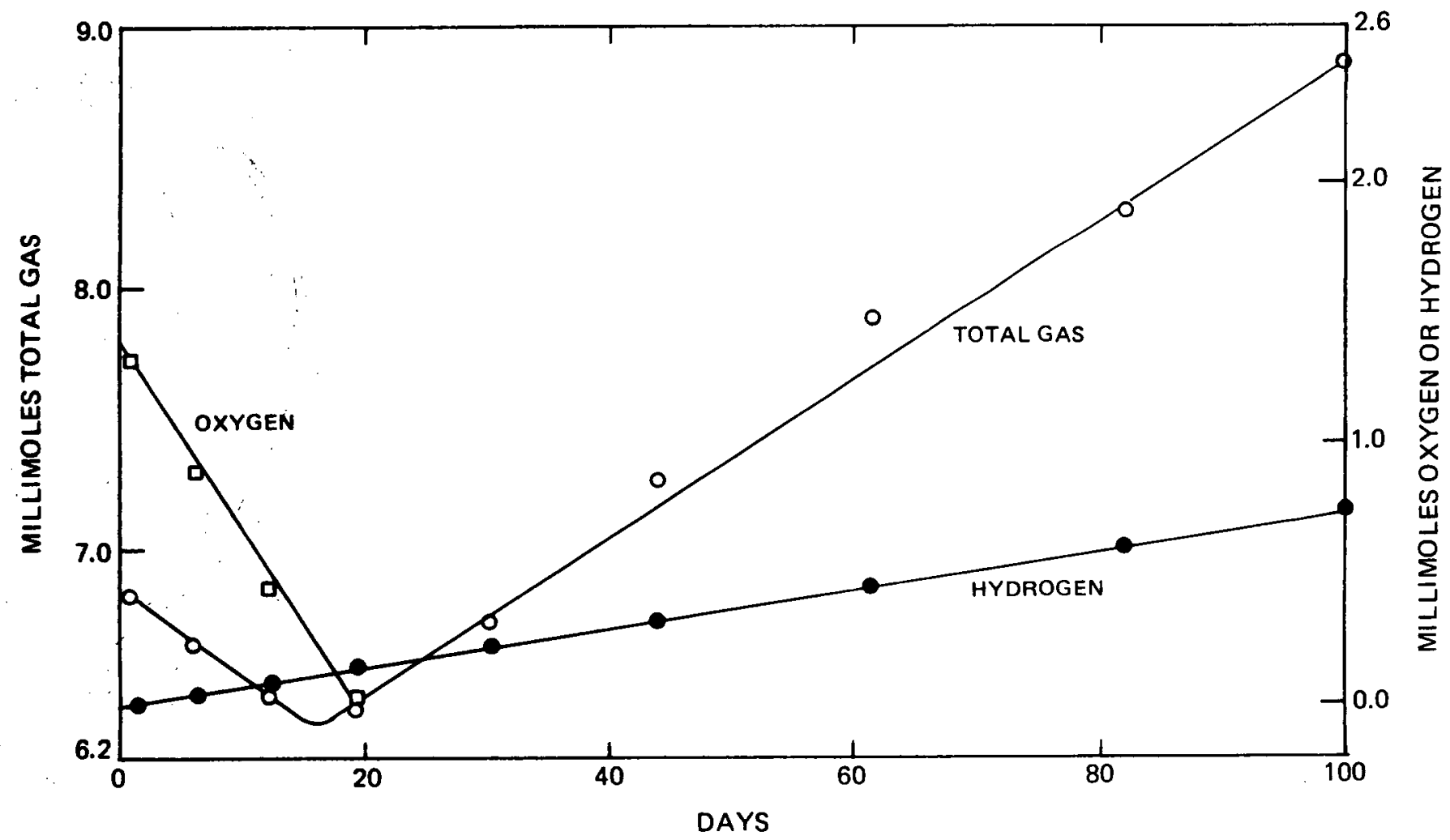


RFP-2469

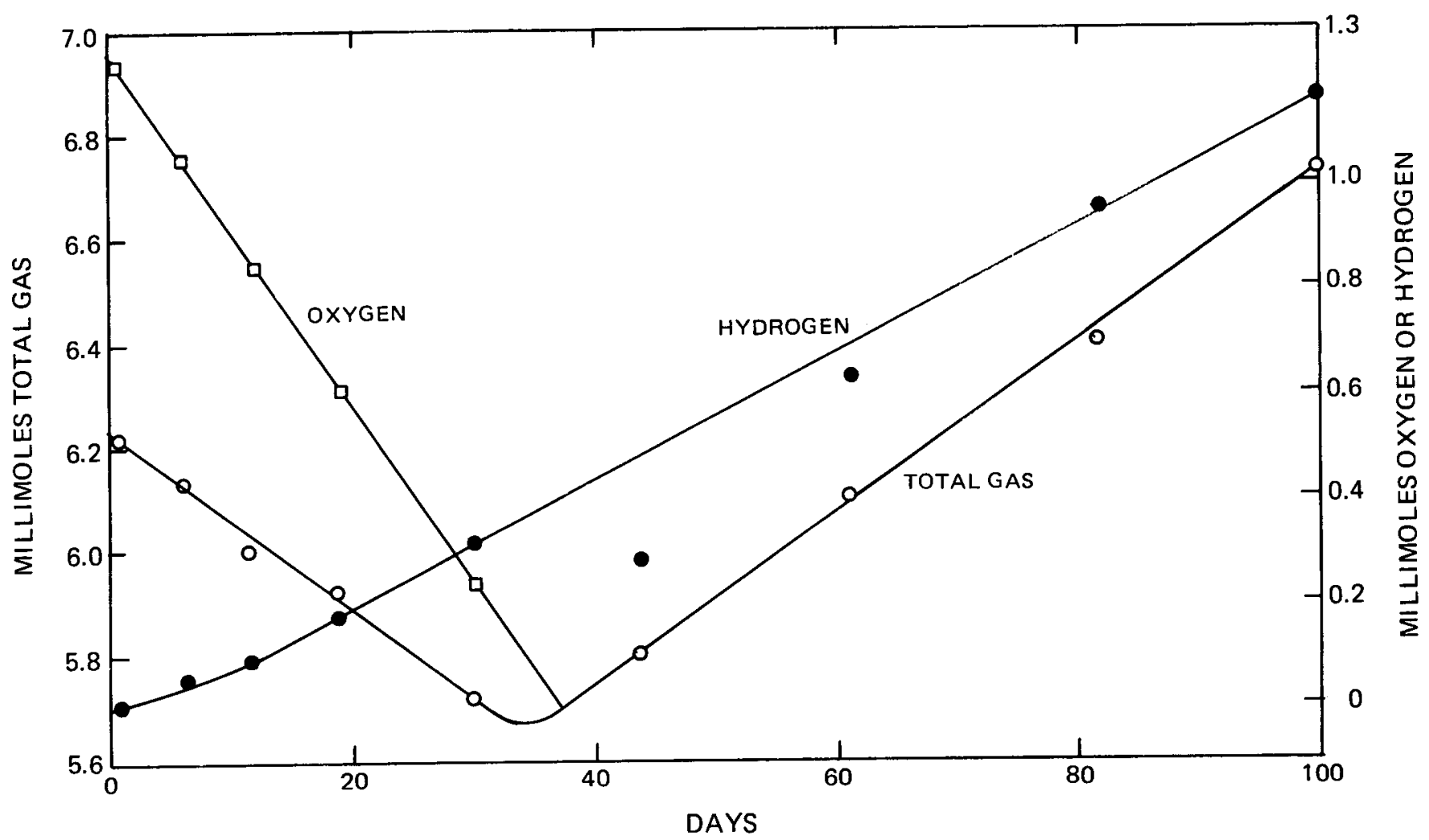

FIGURE 2. Polyvinyl Chloride, Gas Production and Oxygen Depletion, Irradiation from Plutonium 239.

FIGURE 3. Glove-Box Gloves, Gas Production and Oxygen Depletion, Irradiation from Plutonium 239.

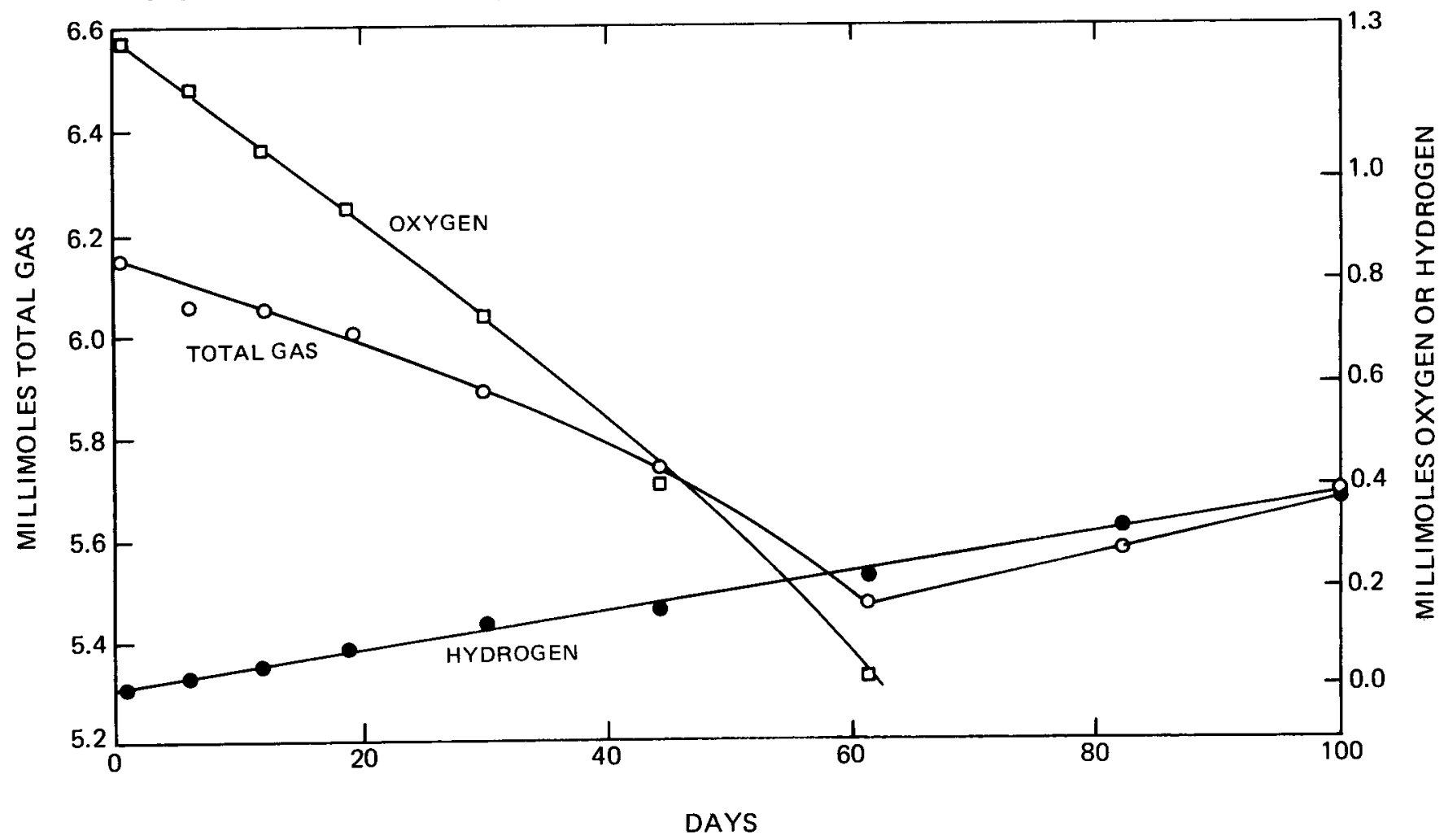


RFP-2469

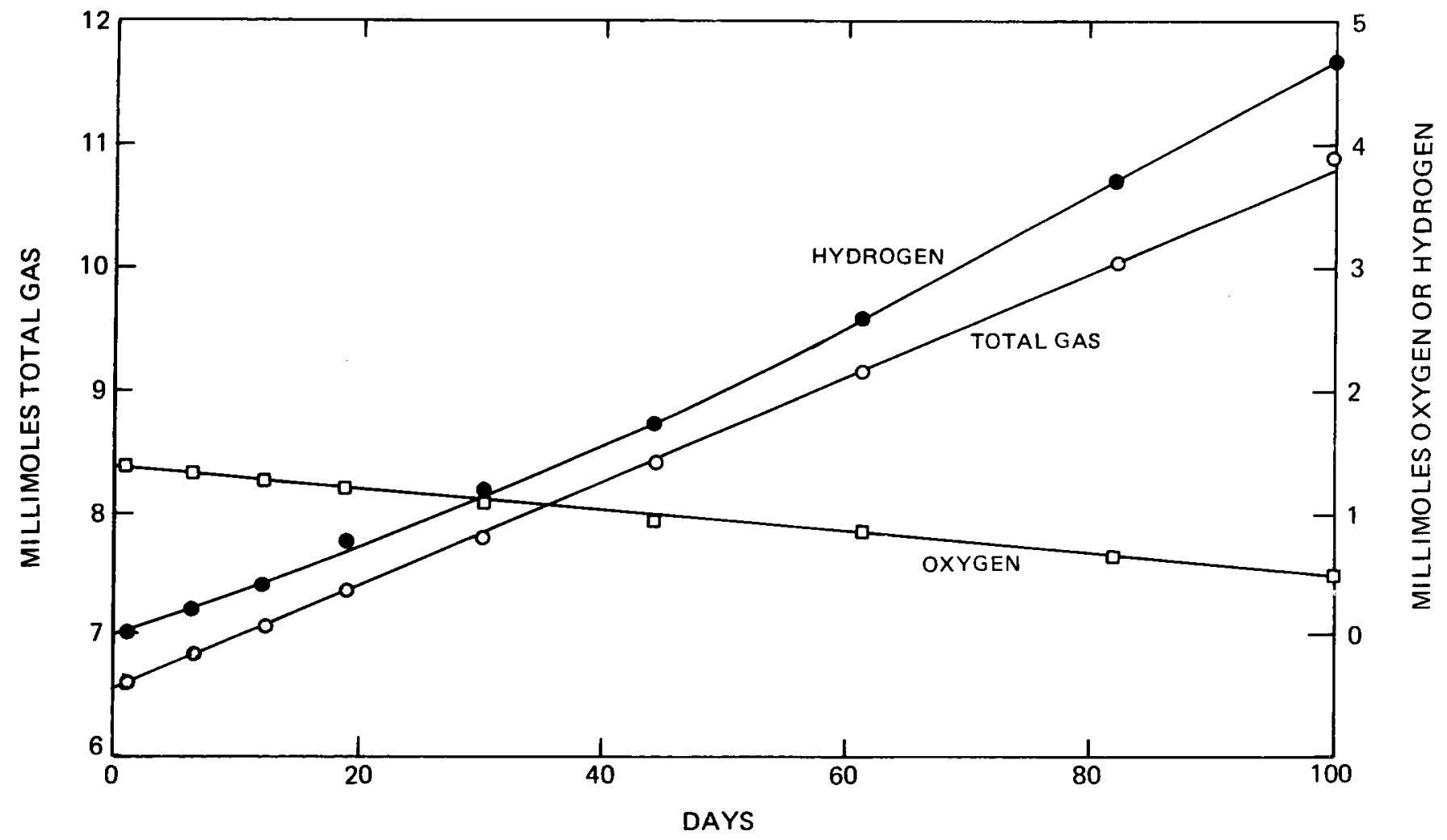

FIGURE 4. Texaco Oil, Gas Production and Oxygen Depletion, Irradiation from Plutonium 239.

FIGURE 5. Carbon Tetrachloride, Gas Production and Oxygen Depletion, Irradiation from Plutonium 239.

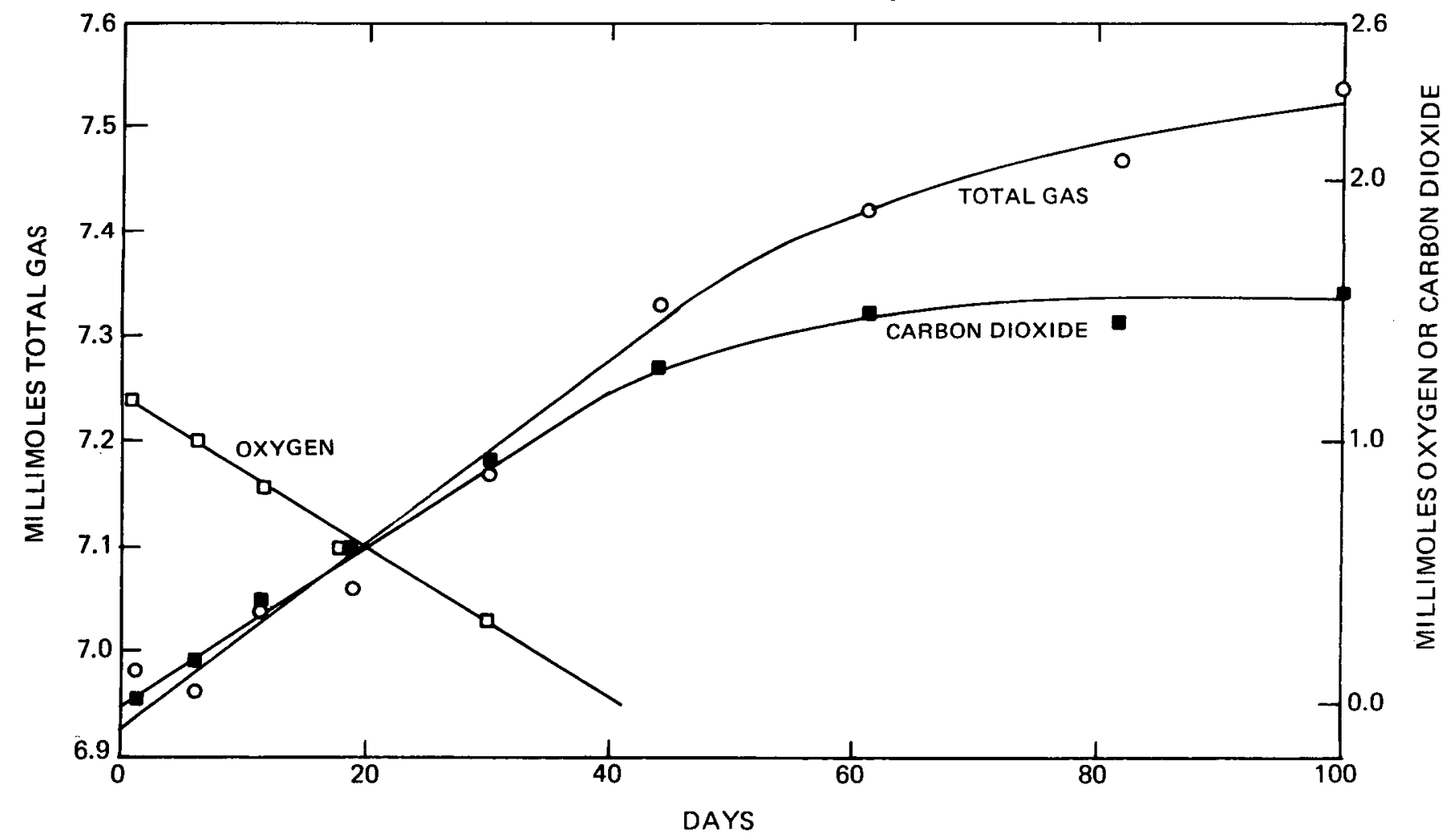


RFP-2469

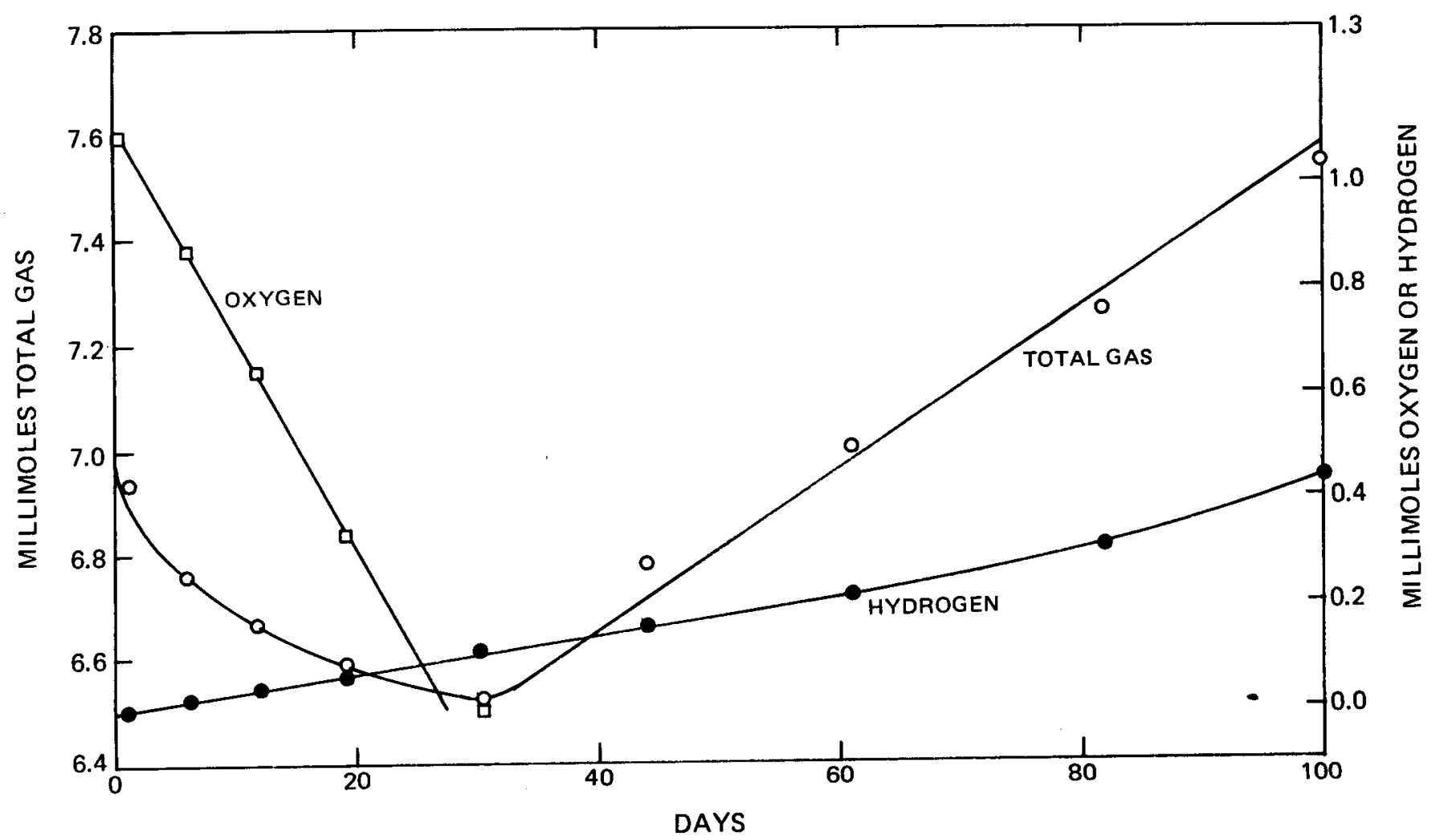

FIGURE 6. Chlorothene ${ }^{\circledR}$, Gas Production and Oxygen Depletion, Irradiation from Plutonium 239.

FIGURE 7. Plexiglas, Gas Production after Evacuation at 120 Days, Irradiation from Plutonium 239.

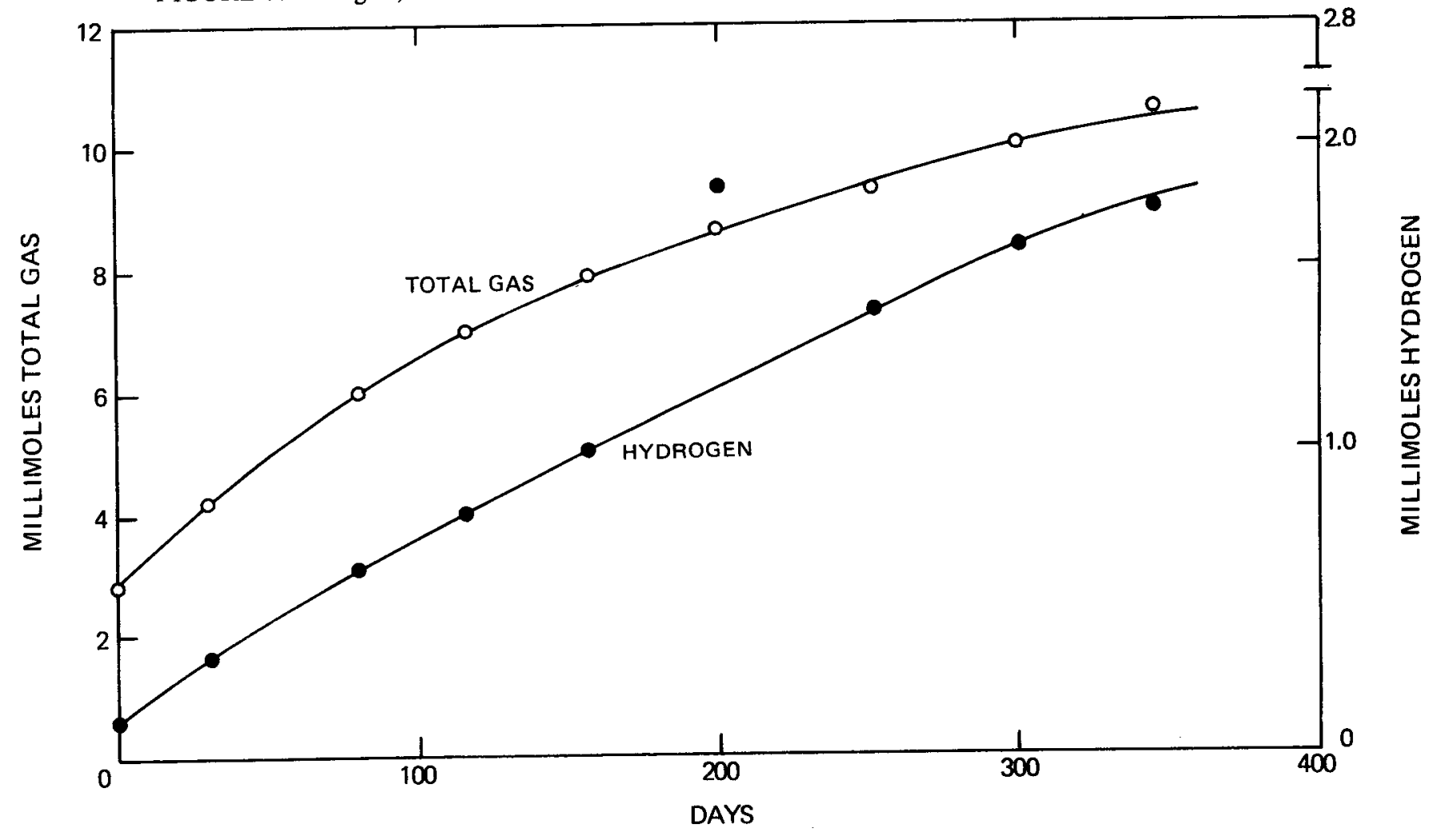




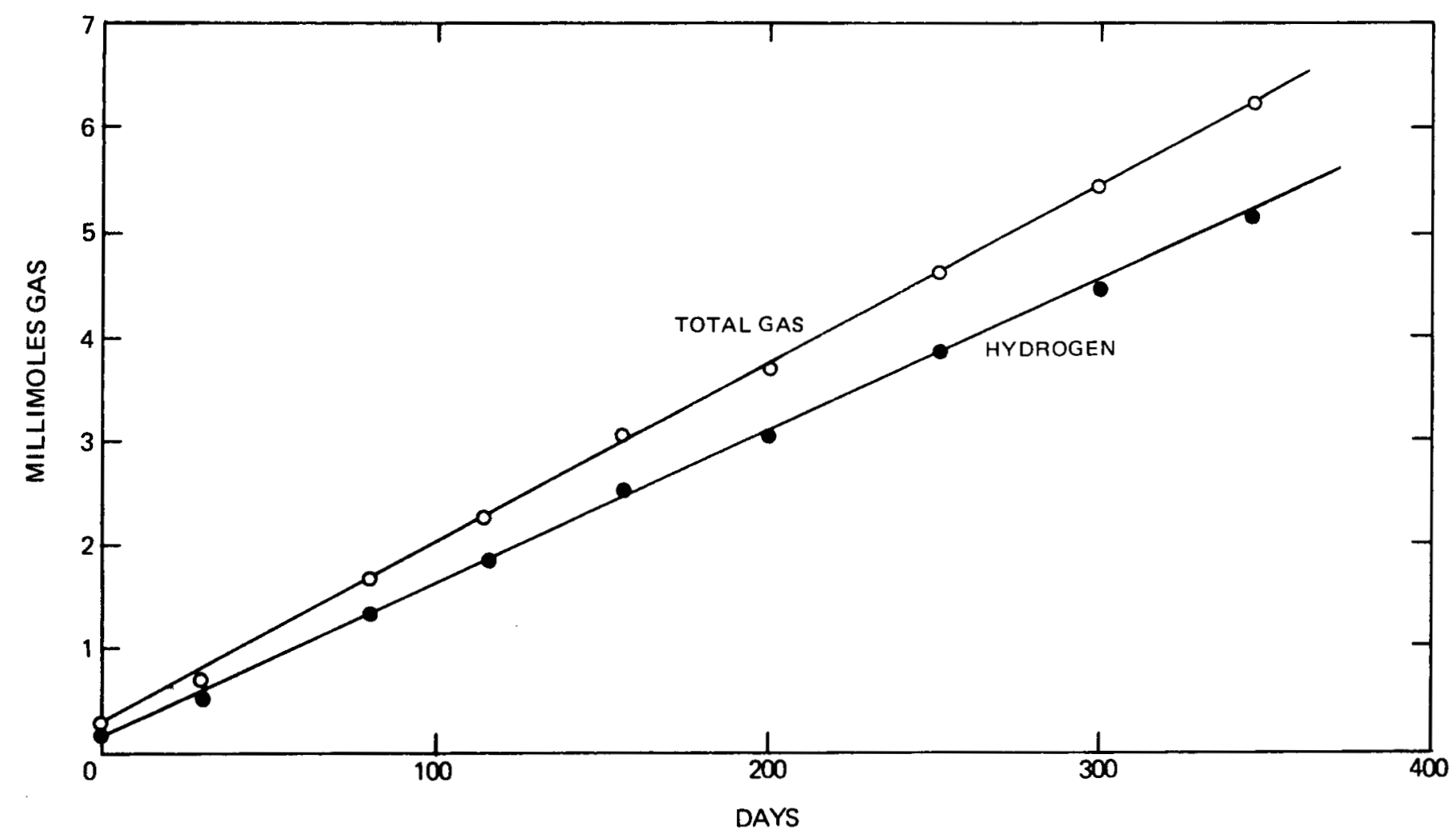

FIGURE 8. Polyvinyl Chloride, Gas Production after Evacuation at 120 Days, Irradiation from Plutonium 239.

FIGURE 9. Glove-Box Gloves, Gas Production after Evacuation at 120 Days, Irradiation from Plutonium 239.

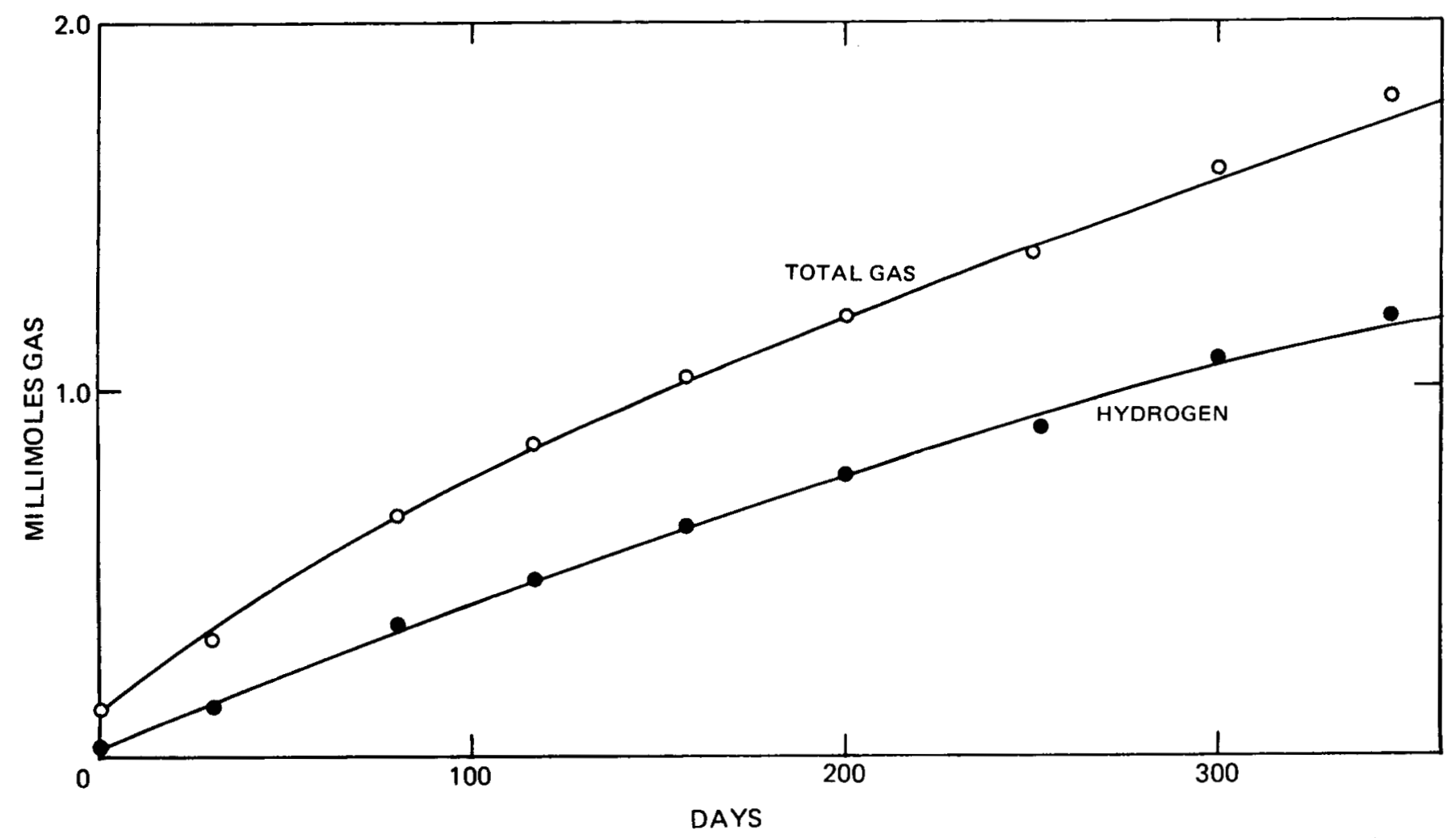


RFP-2469

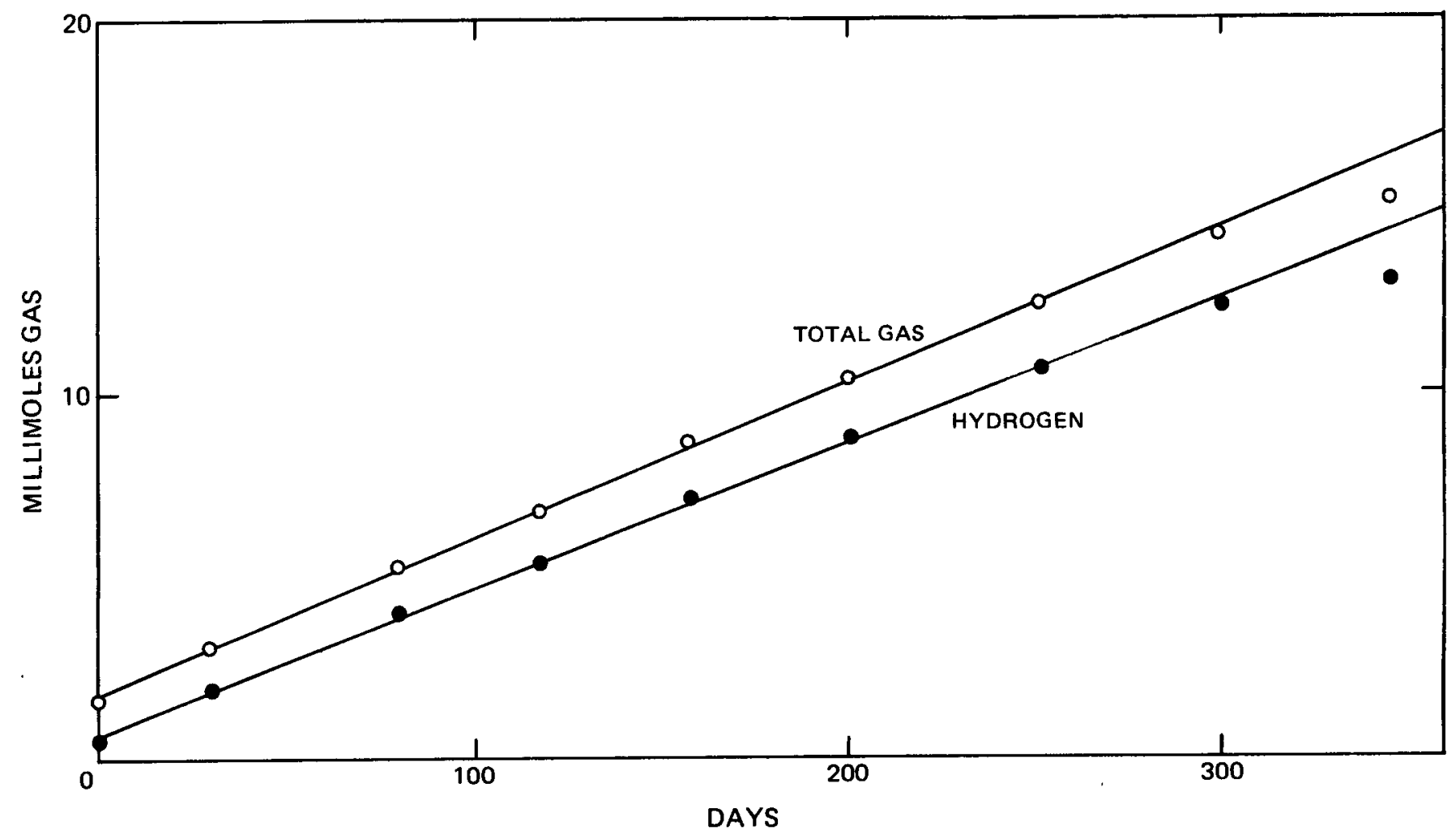

FIGURE 10. Texaco Regal-A Oil, Gas Production after Evacuation at 120 Days, Irradiation from Plutonium 239.

FIGURE 11. Chlorothene $\circledast$, Gas Production after Evacuation at 120 Days, Irradiation from Plutonium 239.

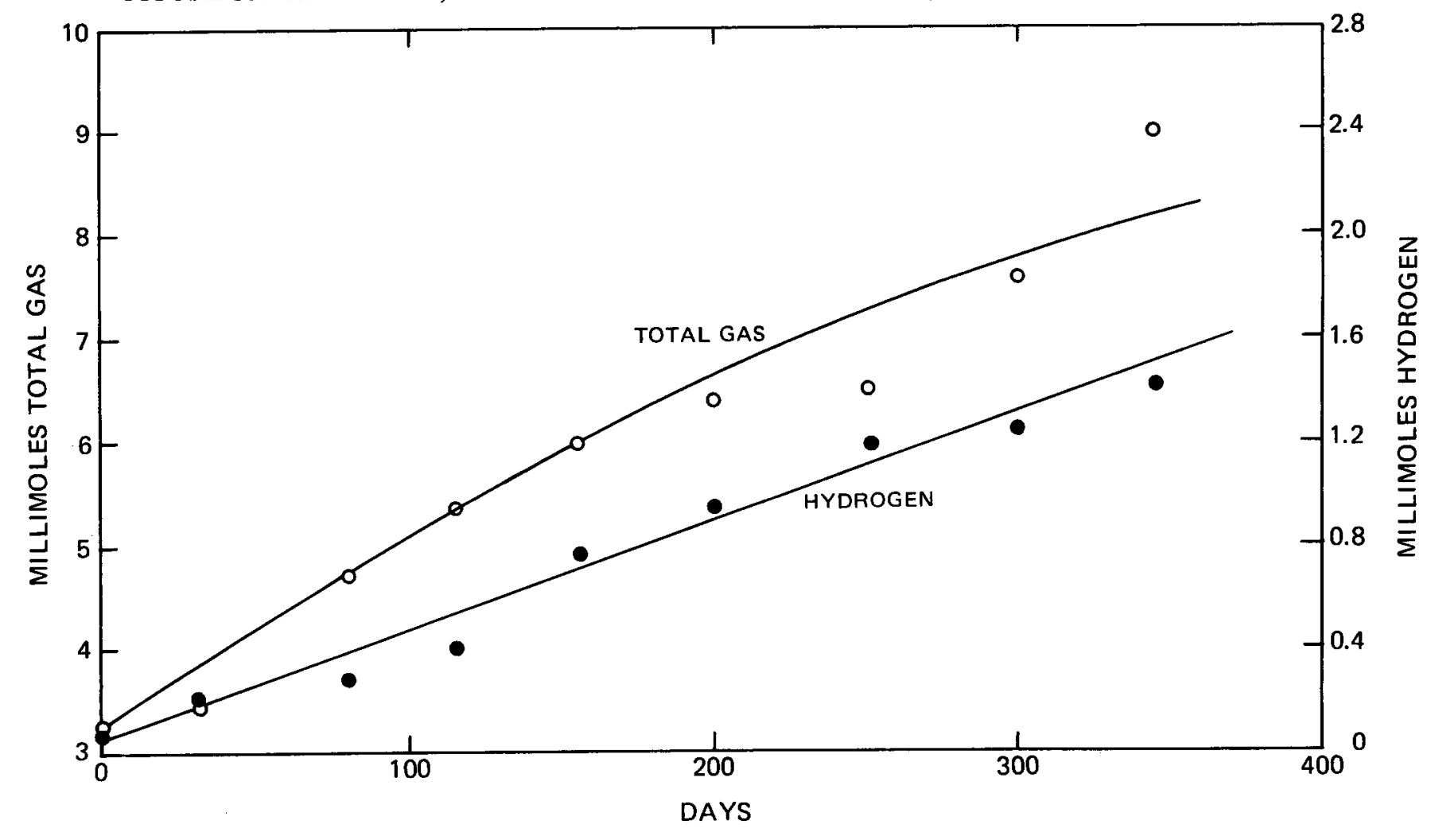




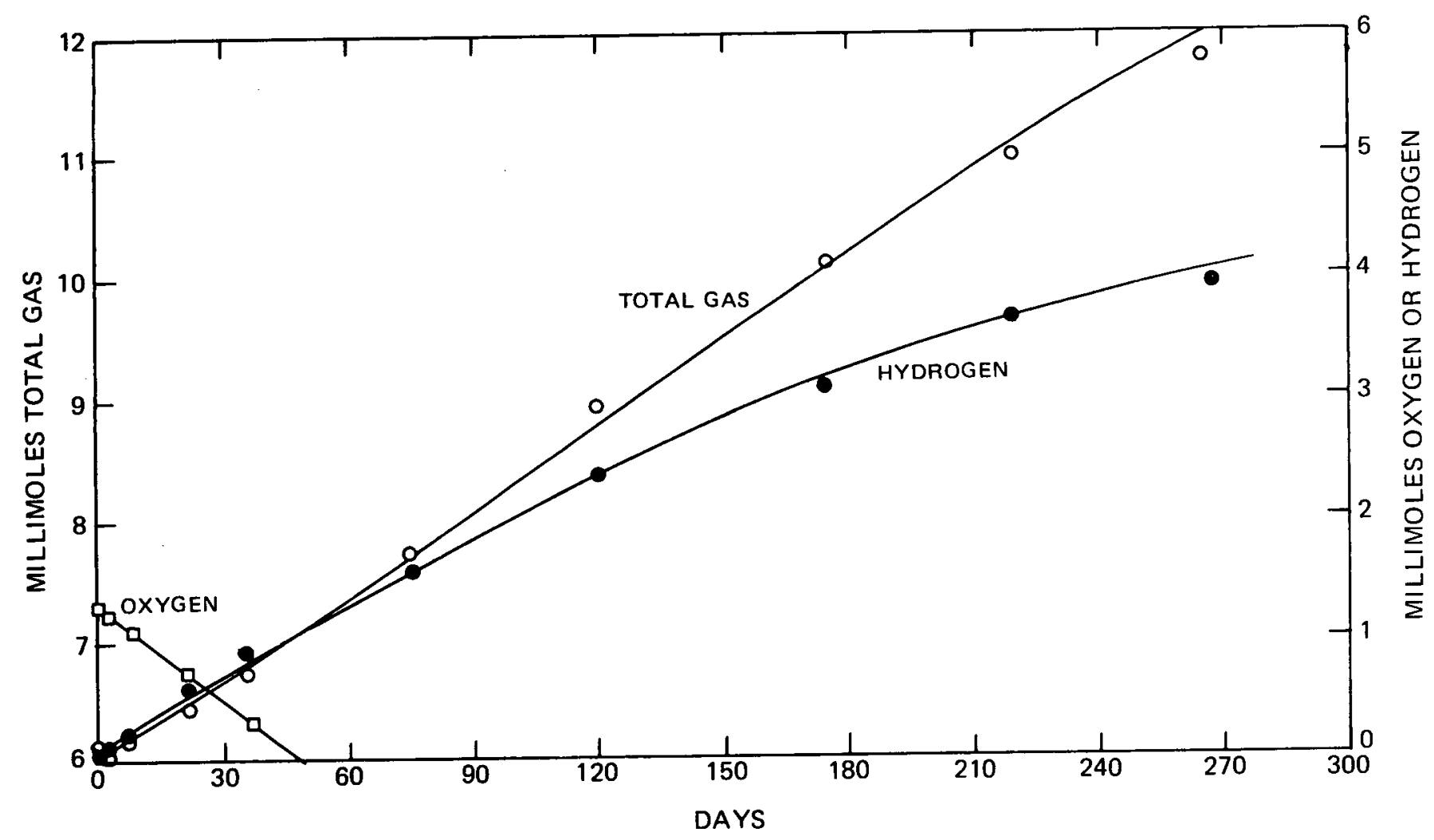

FIGURE 12. Kimwipes®, Dry, Gas Production and Oxygen Depletion, Irradiation from Plutonium 238.

FIGURE 13. Kimwipes®, Wet, Gas Production and Oxygen Depletion, Irradiation from Plutonium 238.

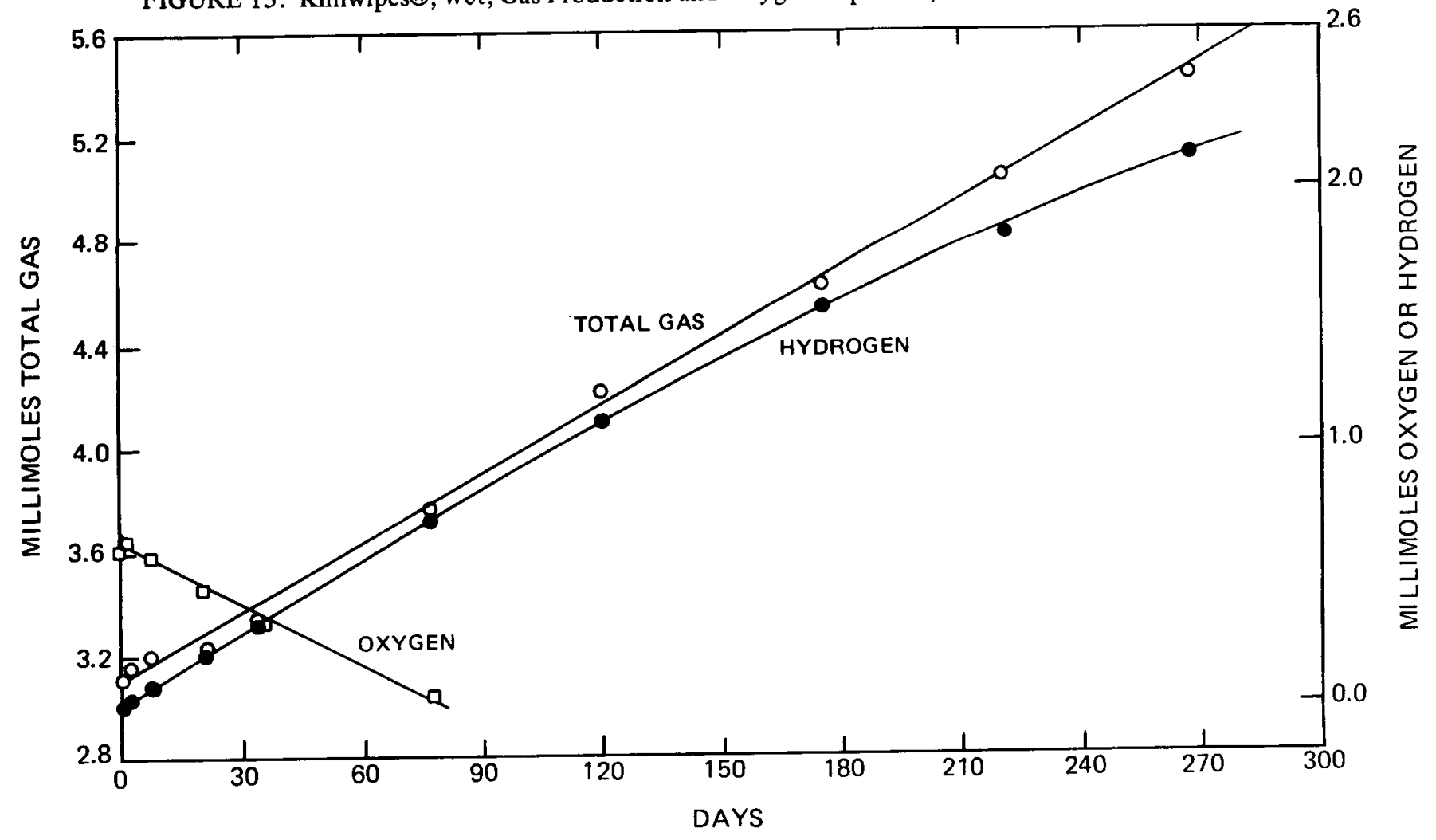


RFP-2469

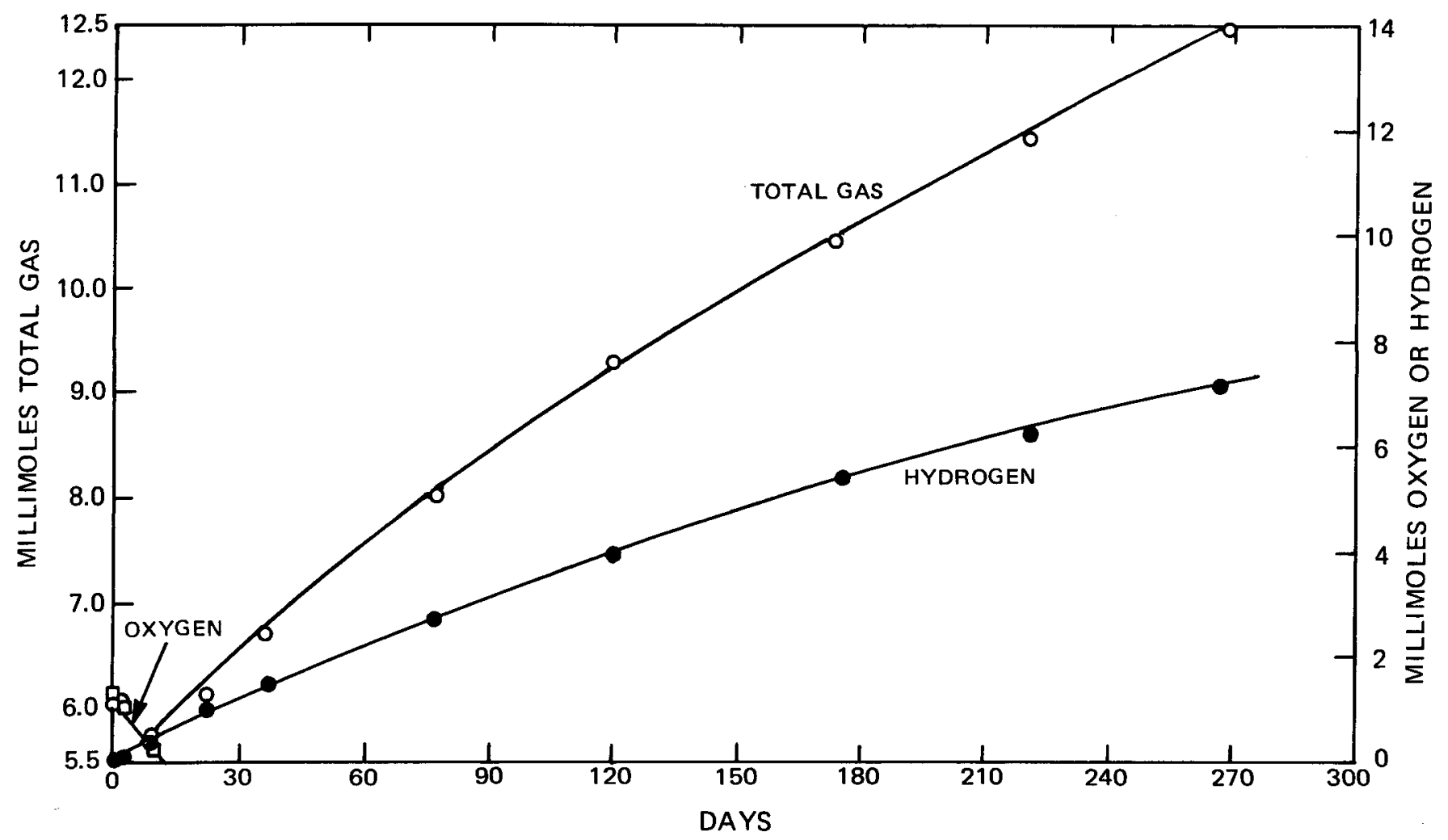

FIGURE 14. Polyethylene, Gas Production and Oxygen Depletion, Irradiation from Plutonium 238.

FIGURE 15. Polyvinyl Chloride, Gas Production and Oxygen Depletion, Irradiation from Plutonium 238.

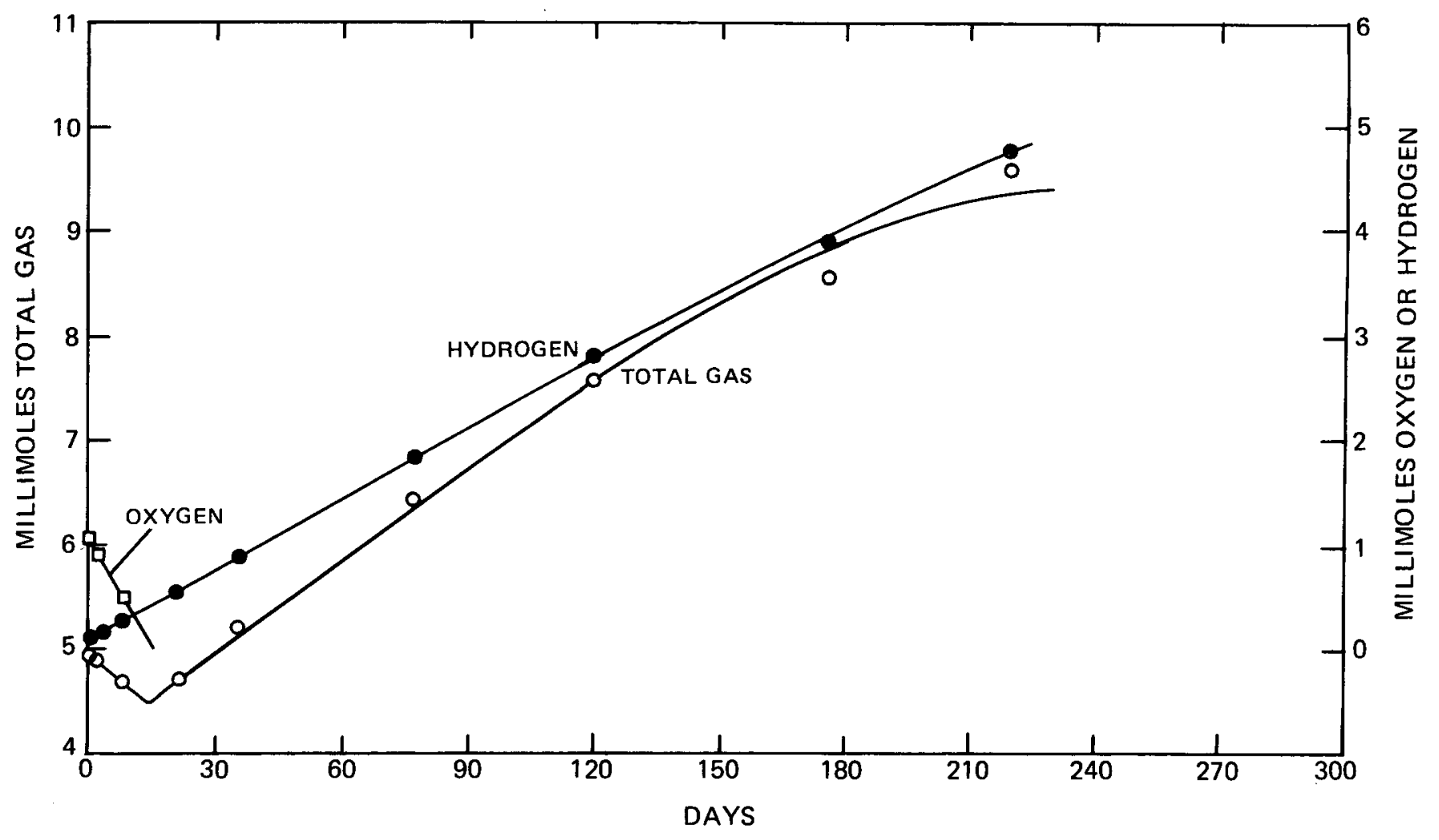




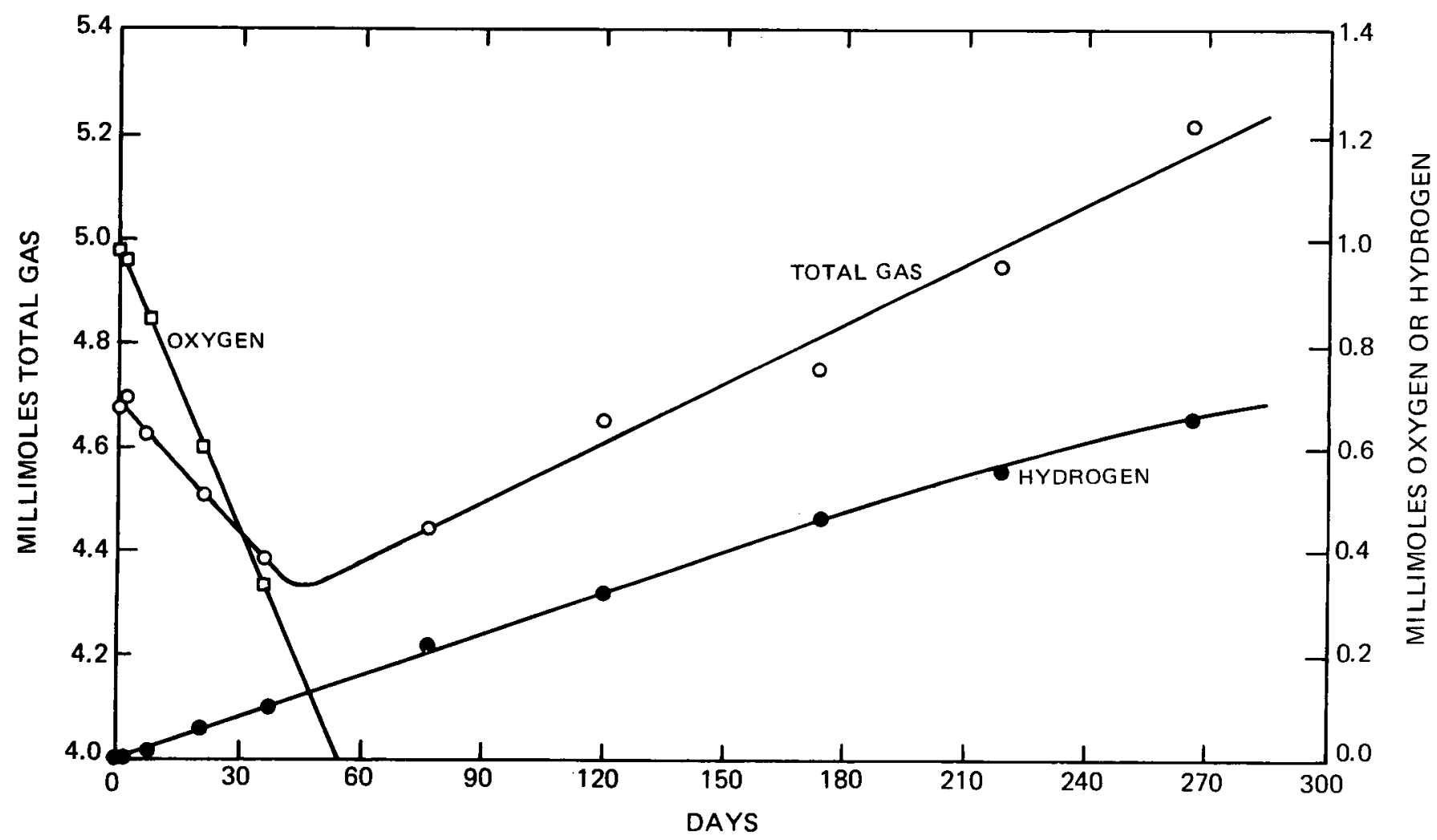

FIGURE 16. Ion Exchange Resin, Gas Production and Oxygen Depletion, Irradiation from Plutonium 238.

FIGURE 17. Surgeon's Gloves, Gas Production and Oxygen Depletion, Irradiation from Plutonium 238.

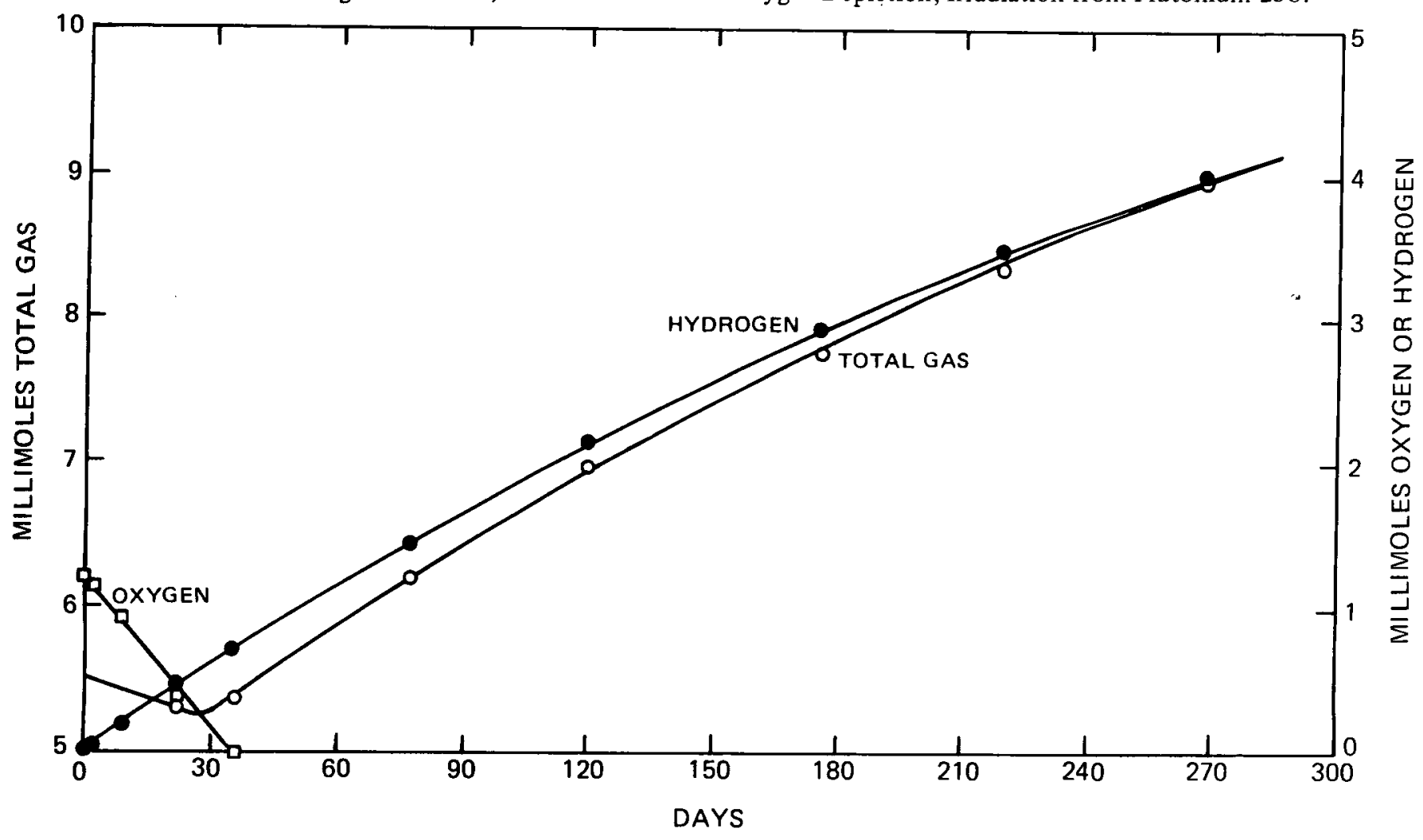




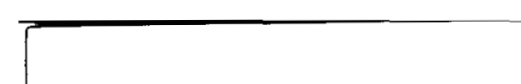

RFP-2469 